\title{
mRNA therapeutics in cancer immunotherapy
}

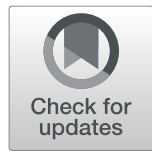

Jan D. Beck ${ }^{1 \dagger} \mathbb{D}$, Daniel Reidenbach ${ }^{2 \dagger} \mathbb{D}$, Nadja Salomon $^{2 \dagger} \mathbb{D}$, Ugur Sahin $^{1} \mathbb{B}$, Özlem Türeci', Mathias Vormehr ${ }^{1+}$ (D) and Lena M. Kranz ${ }^{1 * \dagger}$ (D)

\begin{abstract}
Synthetic mRNA provides a template for the synthesis of any given protein, protein fragment or peptide and lends itself to a broad range of pharmaceutical applications, including different modalities of cancer immunotherapy. With the ease of rapid, large scale Good Manufacturing Practice-grade mRNA production, mRNA is ideally poised not only for off-the shelf cancer vaccines but also for personalized neoantigen vaccination. The ability to stimulate pattern recognition receptors and thus an anti-viral type of innate immune response equips mRNA-based vaccines with inherent adjuvanticity. Nucleoside modification and elimination of double-stranded RNA can reduce the immunomodulatory activity of mRNA and increase and prolong protein production. In combination with nanoparticle-based formulations that increase transfection efficiency and facilitate lymphatic system targeting, nucleoside-modified mRNA enables efficient delivery of cytokines, costimulatory receptors, or therapeutic antibodies. Steady but transient production of the encoded bioactive molecule from the mRNA template can improve the pharmacokinetic, pharmacodynamic and safety properties as compared to the respective recombinant proteins. This may be harnessed for applications that benefit from a higher level of expression control, such as chimeric antigen receptor (CAR)-modified adoptive T-cell therapies. This review highlights the advancements in the field of mRNA-based cancer therapeutics, providing insights into key preclinical developments and the evolving clinical landscape.
\end{abstract}

Keywords: Cancer immunotherapy, Messenger RNA, Cancer vaccines, Antibodies, Immunomodulatory proteins, Immunoreceptors, CARs

\section{Structure and pharmacology of synthetic mRNA} mRNA was long considered insufficiently stable for pharmaceutical applications, given its susceptibility to rapid degradation by ubiquitous RNases. Over the last 30 years, extensive efforts have been made to increase intracellular stability, translational efficiency and uptake of mRNA. These optimizations were achieved by modification of its non-coding elements (5' cap structure and its capping efficiency [1-4], 5'- and $3^{\prime}$-untranslated

\footnotetext{
* Correspondence: lena.kranz@biontech.de

${ }^{\dagger}$ Jan D. Beck, Daniel Reidenbach and Nadja Salomon contributed equally among these three. Mathias Vormehr and Lena M. Kranz contributed equally among these two.

${ }^{1}$ BioNTech SE, An der Goldgrube 12, 55131 Mainz, Germany

Full list of author information is available at the end of the article
}

regions (UTRs) [5-9], 3' poly(A) tail $[5,10,11])$ and of the coding region [12], and through the development of transfection and formulation technologies (Fig. 1).

Building on these advances, synthetic mRNA has emerged as a versatile delivery system for genetic information to induce the production of peptides and proteins by cells.

Synthetic mRNA is single-stranded (ss), contains a $5^{\prime}$ cap, UTRs embracing the coding region and a $3^{\prime}$ poly(A) tail, thus resembling naturally occurring processed mature mRNA molecules, and is generated by in vitro transcription (IVT) from a linear DNA template. Exogenous mRNA enters the cell either by directly passing through the cytoplasmic membrane (e.g., if electroporated), or by

(c) The Author(s). 2021 Open Access This article is licensed under a Creative Commons Attribution 4.0 International License, which permits use, sharing, adaptation, distribution and reproduction in any medium or format, as long as you give appropriate credit to the original author(s) and the source, provide a link to the Creative Commons licence, and indicate if changes were made. The images or other third party material in this article are included in the article's Creative Commons licence, unless indicated otherwise in a credit line to the material. If material is not included in the article's Creative Commons licence and your intended use is not permitted by statutory regulation or exceeds the permitted use, you will need to obtain permission directly from the copyright holder. To view a copy of this licence, visit http://creativecommons.org/licenses/by/4.0/. The Creative Commons Public Domain Dedication waiver (http://creativecommons.org/publicdomain/zero/1.0/) applies to the data made available in this article, unless otherwise stated in a credit line to the data. 


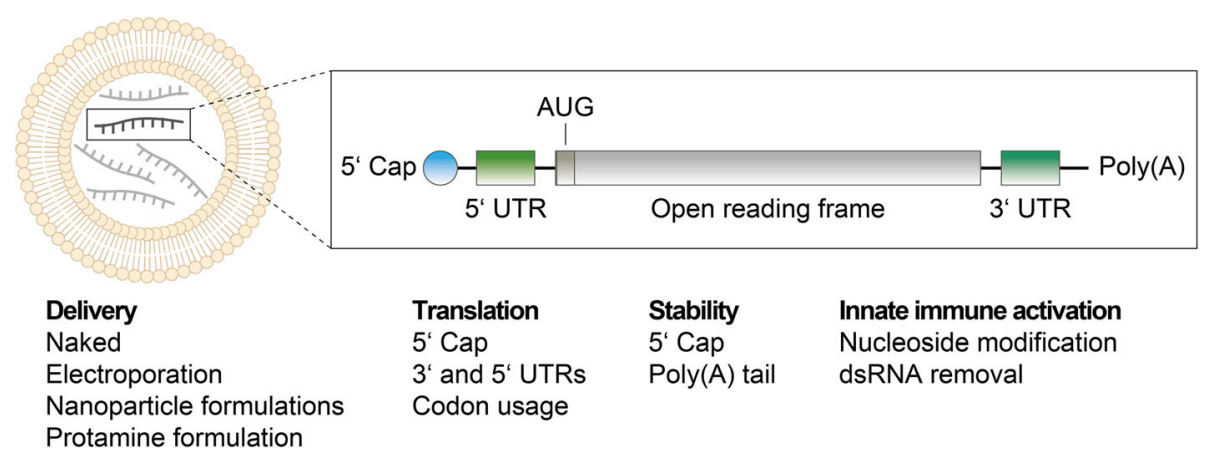

Fig. 1 Delivery and structural elements of mRNA therapeutics. Structure of a lipid-based mRNA nanoparticle (left) and synthetic mRNA (right), comprising a 5' cap, 5' and 3' UTRs, a start codon initiating the open reading frame (AUG), and a poly(A) tail. Listed are different mRNA delivery methods, as well as tunable structural elements influencing mRNA translation, stability and potential of innate immune activation. UTR: untranslated region; ds: double-stranded

endocytosis followed by endosomal escape (if delivered as naked or formulated mRNAs). mRNA does not enter the nucleus, nor integrates into the genome. Translation occurs in the cytosol and the protein derived from the synthetic mRNA is not distinguishable from protein translated from endogenous mRNA. The protein undergoes post-translational modifications and is routed to subcellular compartments, such as the secretory pathway, the cell membrane, the nucleus, mitochondria or peroxisomes, via targeting sequences or transmembrane domains. Eventually, the protein is degraded and peptides are presented on major histocompatibility (MHC) complexes.

In parallel to its translation to protein, exogenous mRNA exerts its activity as a natural ligand of endosomal toll-like receptors (TLRs) 3, 7 and 8, or of retinoic acid-inducible gene 1 (RIG-I) and melanoma differentiation-associated protein 5 (MDA5) in the cytoplasm, and triggers the release of type I interferon (IFN) and pro-inflammatory cytokines (reviewed in Pastor et al. [13]), providing mRNA with strong intrinsic adjuvanticity.

In cancer immunotherapy, the most advanced application of mRNA is therapeutic vaccination, which leverages both the capability of mRNA to deliver genetic information and its innate immunostimulatory activity. The latter is particularly important for breaking immune tolerance when cancer-associated self-antigens are targeted. However, IFN-stimulated genes (ISGs), such as IFN-inducible double-stranded (ds)RNA-activated protein kinase (PKR), and 2',5'-oligoadenylate synthetase (OAS) with subsequent RNase L expression, initiate a state of anti-viral defense, characterized by stalled mRNA translation and increased targeting of mRNA for degradation (reviewed in Kroczynska et al. [14], Munir et al. [15]). Other applications of mRNA in cancer immunotherapy include the engineering of $\mathrm{T}$ cells and natural killer (NK) cells with antigen receptors, and its use as a template for immunologically active proteins in a variety of immune and non-immune cells (Fig. 2). Several of these applications rely more heavily on a high area under the curve (AUC) of mRNA translation, and stalled translation is not desirable. Immunostimulatory activity of mRNA can be attenuated by modified nucleosides, such as pseudouridine, $\mathrm{N}^{1}$-methylpseudouridine, 2-thiouridine, 5-methylcytidine or $\mathrm{N}^{6}$-methyladenosine [16-19], and by the removal of dsRNA [20, 21]. Throughout this review, mRNA nucleoside modifications are explicitly indicated where applicable.

With the global threat of the COVID-19 pandemic accelerating rapid-response vaccine development, mRNAbased therapeutics were shown to deliver on their promise: active at a relatively low dose range, can be developed rapidly, and GMP-compliant manufacturing processes easily upscaled for rapid availability of large numbers of doses [22-24]. It is to be expected that lessons learned in the context of COVID-19 vaccine development can be leveraged to further advance the development of mRNA-based cancer immunotherapies.

\section{mRNA-based cancer vaccines}

Cancer vaccination involves the induction of tumorspecific T-cell responses potentially capable of tumor rejection by providing cancer antigens in the context of immunostimulation. Some cancer vaccines targeting surface exposed antigens additionally aim at inducing a tumor-specific B-cell response. Antigens are either tumor-associated self antigens (TAA), such as differentiation antigens, overexpressed antigens, cancer/testis antigens, or truly tumor-specific antigens (TSAs) not subject to immune tolerance, such as viral and mutated neoantigens. Various formats can be used for antigen delivery, including viral vectors, DNA, peptides, mRNA, or dendritic cells (DCs) pulsed with any of these.

mRNA has emerged as an attractive cancer vaccine format as it provides both antigen delivery and innate 


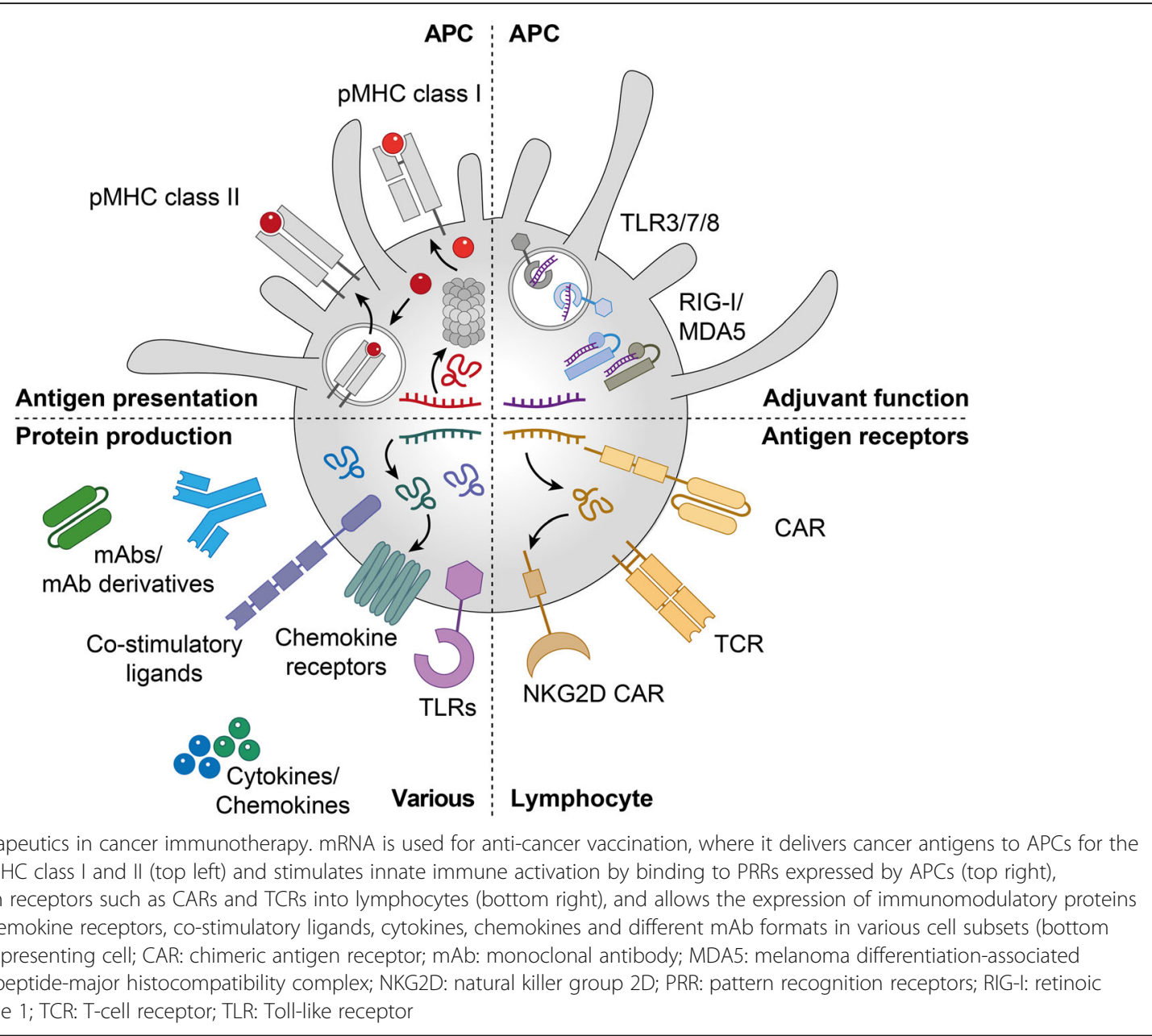

immune activation-mediated co-stimulation in a spatiotemporally aligned manner. mRNA vaccines encode the full or partial sequence of a TSA or TAA, and do not rely on prior identification of a patient's human leukocyte antigen (HLA) haplotype or epitope prediction.

The feasibility of mRNA-based cancer vaccination was first demonstrated about 25 years ago [25, 26]. Since then, numerous preclinical and clinical studies explored mRNA for anti-cancer vaccination, either by loading it ex vivo on autologous DCs for adoptive transfer or by direct injection. A summary of all active, and completed or terminated phase II and III clinical trials using mRNA vaccines is provided in Table 1.

\section{mRNA-based DC vaccines}

As professional antigen presenting cells (APCs), DCs constantly engulf cellular material from their surroundings. To efficiently deliver tumor antigen to DCs, many early studies focused on ex vivo DC loading and reinfusion of the transfected cells to patients via the subcutaneous, intranodal (injected into a particular lymph node) or intravenous route. The generation of DC vaccines requires isolation of monocytes or hematopoietic progenitor cells from the blood (leukapheresis), ex vivo cultivation, differentiation and tumor-antigen loading and is labor-intensive, costly and complex (detailed review by Perez et al. [47]).

\section{Loading DCs with tumor antigens}

One of the approaches to pulse DCs with mRNA encoding tumor antigens is the use of bulk mRNA extracted from autologous tumors. Whole tumor mRNA-loaded DC vaccines demonstrated safety in phase I and I/II clinical trials in patients with renal cell carcinoma (RCC; NCT00006431) [48], pediatric and adult brain cancer [49], pediatric neuroblastoma [50], melanoma (NCT01278940) [51], and androgen-resistant prostate cancer [52]. In a phase I/II study (NCT01278940), whole tumor mRNA-transfected DC vaccines were administered alone or together with interleukin (IL)-2 and induced T-cell responses against mRNA-transfected DCs ex vivo in 16 of the 31 patients with advanced melanoma [53]. Immune-responders exhibited significantly 
Table 1 List of all active, and completed or terminated phase II/III clinical trials of mRNA vaccines in cancer therapy

\begin{tabular}{|c|c|c|c|c|c|c|}
\hline Sponsor & $\begin{array}{l}\text { Vaccine type } \\
\text { (delivery route) }\end{array}$ & Indication & $\begin{array}{l}\text { ClinicalTrial.gov identifier } \\
\text { (phase, allocation) }\end{array}$ & Combination & Opened & Status \\
\hline \multicolumn{7}{|l|}{ DC vaccine } \\
\hline \multirow{4}{*}{$\begin{array}{l}\text { Antwerp } \\
\text { University } \\
\text { Hospital }\end{array}$} & \multirow[t]{4}{*}{ WT1 mRNA (i.d.) } & $\begin{array}{l}\text { Myeloid leukemia, } \\
\text { multiple myeloma }\end{array}$ & NCT00965224 (II, randomized) & Standard-of-care & 2009 & $\begin{array}{l}\text { Unknown } \\
{[27]}\end{array}$ \\
\hline & & AML & NCT01686334 (II, randomized) & $\begin{array}{l}\text { Conventional } \\
\text { chemotherapy }\end{array}$ & 2012 & Recruiting \\
\hline & & GBM & NCT02649582 (I/II) & $\begin{array}{l}\text { Temozolomide, } \\
\text { temozolomide-based } \\
\text { chemoradiation }\end{array}$ & 2015 & Recruiting \\
\hline & & $\begin{array}{l}\text { Malignant pleural } \\
\text { mesothelioma }\end{array}$ & NCT02649829 (I/II) & $\begin{array}{l}\text { Conventional } \\
\text { chemotherapy }\end{array}$ & 2017 & Recruiting \\
\hline \multirow[t]{2}{*}{$\begin{array}{l}\text { Argos } \\
\text { Therapeutics }\end{array}$} & \multirow{2}{*}{$\begin{array}{l}\text { Total tumor mRNA } \\
\text { and CD40L mRNA } \\
\text { (i.d.) }\end{array}$} & \multirow[t]{2}{*}{$\mathrm{RCC}$} & NCT00678119 (Il, single arm) & \multirow[t]{2}{*}{$\begin{array}{l}\text { Standard-of-care } \\
\text { (sunitinib) }\end{array}$} & 2008 & $\begin{array}{l}\text { Completed } \\
\text { [28] }\end{array}$ \\
\hline & & & $\begin{array}{l}\text { NCT01582672 (III, } \\
\text { randomized) }\end{array}$ & & 2012 & $\begin{array}{l}\text { Terminated } \\
\text { (Lack of } \\
\text { effiacy) [29, } \\
\text { 30] }\end{array}$ \\
\hline $\begin{array}{l}\text { Asterias } \\
\text { Biotherapeutics, } \\
\text { Inc. }\end{array}$ & $\begin{array}{l}\text { hTERT mRNA with a } \\
\text { LAMP-1 targeting } \\
\text { sequence (i.d.) }\end{array}$ & $\begin{array}{l}\text { AML (complete } \\
\text { remission) }\end{array}$ & NCT00510133 (Il, single arm) & None & 2007 & $\begin{array}{l}\text { Completed } \\
\text { [31] }\end{array}$ \\
\hline $\begin{array}{l}\text { Baylor College } \\
\text { of Medicine }\end{array}$ & $\begin{array}{l}\text { Tumor mRNA and } \\
\text { tumor lysate (i.d.) }\end{array}$ & Pancreatic cancer & NCT04157127 (I) & $\begin{array}{l}\text { Adjuvant to } \\
\text { chemotherapy }\end{array}$ & 2020 & Recruiting \\
\hline \multirow[t]{5}{*}{ Duke University } & \multirow[t]{3}{*}{$\begin{array}{l}\text { LAMP-fused HCMV } \\
\text { pp65 mRNA (i.d.) } \\
\text { and td }\end{array}$} & \multirow[t]{2}{*}{$\begin{array}{l}\text { Malignant neoplasms } \\
\text { of brain }\end{array}$} & NCT00639639 (I) & None & 2006 & $\begin{array}{l}\text { Active, not } \\
\text { recruiting } \\
\text { [32] }\end{array}$ \\
\hline & & & NCT02366728 (II, randomized) & $\begin{array}{l}\text { Temozolomide, } \\
\text { basiliximab } \\
\text { (antagonistic } \\
\text { anti-CD25) }\end{array}$ & 2015 & $\begin{array}{l}\text { Active, not } \\
\text { recruiting } \\
\text { [33] }\end{array}$ \\
\hline & & Glioblastoma & NCT03688178 (II, randomized) & $\begin{array}{l}\text { Temozolomide, } \\
\text { varlilumab } \\
\text { (agonistic } \\
\text { anti-CD27) }\end{array}$ & 2020 & Recruiting \\
\hline & \multirow{2}{*}{$\begin{array}{l}\text { LAMP-fused HCMV } \\
\text { pp65 mRNA, GM-CSF } \\
\text { (i.d.) and td }\end{array}$} & $\begin{array}{l}\text { Malignant neoplasms } \\
\text { of brain }\end{array}$ & NCT03615404 (I) & None & 2018 & $\begin{array}{l}\text { Active, not } \\
\text { recruiting }\end{array}$ \\
\hline & & Glioblastoma & NCT03927222 (II, single arm) & Temozolomide & 2019 & Recruiting \\
\hline \multirow[t]{3}{*}{$\begin{array}{l}\text { Guangdong } 999 \\
\text { Brain Hospital }\end{array}$} & \multirow[t]{2}{*}{ Tumor mRNA } & $\begin{array}{l}\text { Brain cancer, } \\
\text { neoplasm metastasis }\end{array}$ & NCT02808416 (I) & None & 2016 & $\begin{array}{l}\text { Active, not } \\
\text { recruiting }\end{array}$ \\
\hline & & $\begin{array}{l}\text { Recurrent } \\
\text { glioblastoma }\end{array}$ & NCT02808364 (I) & None & 2016 & $\begin{array}{l}\text { Active, not } \\
\text { recruiting }\end{array}$ \\
\hline & $\begin{array}{l}\text { Glioblastoma TAA } \\
\text { mRNA (i.d. and i.v.) }\end{array}$ & Glioblastoma & NCT02709616 (I) & $\begin{array}{l}\text { Conventional } \\
\text { chemo- and } \\
\text { radiotherapy }\end{array}$ & 2016 & $\begin{array}{l}\text { Active, not } \\
\text { recruiting }\end{array}$ \\
\hline $\begin{array}{l}\text { Hasumi } \\
\text { International } \\
\text { Research } \\
\text { Foundation }\end{array}$ & $\begin{array}{l}\text { IKKb-matured DCs } \\
\text { with tumor mRNA, } \\
\text { TAA mRNA (gp100, } \\
\text { tyrosinase, PRAME, } \\
\text { MAGE-A3, IDO) and } \\
\text { neoAg mRNA } \\
\text { (GNAQ/GNA11Q209 } \\
\text { or R183) (i.v.) }\end{array}$ & $\begin{array}{l}\text { Uveal metastatic } \\
\text { melanoma }\end{array}$ & NCT04335890 (I) & None & 2020 & Recruiting \\
\hline Herlev Hospital & $\begin{array}{l}\text { PSA, PAP, survivin, } \\
\text { hTERT mRNA (i.d.) }\end{array}$ & $\begin{array}{l}\text { Metastatic prostate } \\
\text { cancer }\end{array}$ & NCT01446731 (II, randomized) & Docetaxel & 2011 & $\begin{array}{l}\text { Completed } \\
{[34]}\end{array}$ \\
\hline $\begin{array}{l}\text { Immunomic } \\
\text { Therapeutics, } \\
\text { Inc. }\end{array}$ & $\begin{array}{l}\text { HCMV pp65-shLAMP } \\
\text { or pp65-flLAMP, } \\
\text { GM-CSF and td } \\
\text { (both) }\end{array}$ & $\begin{array}{l}\text { GBM, glioblastoma, } \\
\text { malignant glioma, } \\
\text { astrocytoma }\end{array}$ & NCT02465268 (II, randomized) & Temozolomide & 2016 & Recruiting \\
\hline
\end{tabular}


Table 1 List of all active, and completed or terminated phase II/III clinical trials of mRNA vaccines in cancer therapy (Continued)

\begin{tabular}{|c|c|c|c|c|c|c|}
\hline Sponsor & $\begin{array}{l}\text { Vaccine type } \\
\text { (delivery route) }\end{array}$ & Indication & $\begin{array}{l}\text { ClinicalTrial.gov identifier } \\
\text { (phase, allocation) }\end{array}$ & Combination & Opened & Status \\
\hline \multirow{2}{*}{$\begin{array}{l}\text { Memorial Sloan } \\
\text { Kettering Cancer } \\
\text { Center }\end{array}$} & $\begin{array}{l}\text { Langerhans-type DCs } \\
\text { with Trp2 mRNA }\end{array}$ & Melanoma & NCT01456104 (I) & None & 2011 & $\begin{array}{l}\text { Active, not } \\
\text { recruiting }\end{array}$ \\
\hline & $\begin{array}{l}\text { Langerhans-type DCs } \\
\text { with CT7, MAGE-A3, } \\
\text { WT1 mRNA }\end{array}$ & Multiple myeloma & NCT01995708 (I) & Standard-of-care & 2014 & $\begin{array}{l}\text { Active, not } \\
\text { recruiting }\end{array}$ \\
\hline $\begin{array}{l}\text { Oslo University } \\
\text { Hospital }\end{array}$ & $\begin{array}{l}\text { Tumor mRNA and } \\
\text { hTERT, survivin TAA } \\
\text { mRNA }\end{array}$ & Prostate cancer & NCT01197625 (I/II) & None & 2010 & $\begin{array}{l}\text { Active, not } \\
\text { recruiting }\end{array}$ \\
\hline $\begin{array}{l}\text { Radboud } \\
\text { University }\end{array}$ & $\begin{array}{l}\text { Tyrosinase, gp100 } \\
\text { mRNA (i.d. and i.v.) }\end{array}$ & Melanoma & NCT02285413 (II, randomized) & Cisplatin & 2011 & $\begin{array}{l}\text { Completed } \\
\text { [35] }\end{array}$ \\
\hline $\begin{array}{l}\text { University } \\
\text { Hospital } \\
\text { Erlangen }\end{array}$ & Tumor mRNA & Uveal melanoma & $\begin{array}{l}\text { NCT01983748 (III, } \\
\text { randomized) }\end{array}$ & None & 2014 & Recruiting \\
\hline $\begin{array}{l}\text { University of } \\
\text { Campinas }\end{array}$ & WT1 mRNA & $\begin{array}{l}\text { Myelodysplastic } \\
\text { syndromes, AML }\end{array}$ & NCT03083054 (I/II) & None & 2016 & $\begin{array}{l}\text { Active, not } \\
\text { recruiting }\end{array}$ \\
\hline \multirow[t]{2}{*}{$\begin{array}{l}\text { University of } \\
\text { Florida }\end{array}$} & $\begin{array}{l}\text { Total tumor mRNA } \\
\text { and ex vivo expanded } \\
\text { lymphocytes } \\
\text { (i.v. and i.d.) }\end{array}$ & $\begin{array}{l}\text { Medulloblastoma, } \\
\text { neuroectodermal } \\
\text { tumor }\end{array}$ & NCT01326104 (I, II) & None & 2010 & $\begin{array}{l}\text { Active, not } \\
\text { recruiting } \\
{[36]}\end{array}$ \\
\hline & $\begin{array}{l}\text { Total tumor mRNA, } \\
\text { ex vivo expanded } \\
\text { lymphocytes, } \\
\text { GM-CSF and td }\end{array}$ & $\begin{array}{l}\text { Diffuse intrinsic } \\
\text { pontine glioma, Brain } \\
\text { stem glioma }\end{array}$ & NCT03396575 (I) & $\begin{array}{l}\text { Cyclophosphamide } \\
\text { + fludarabine } \\
\text { lymphodepleting } \\
\text { conditioning or } \\
\text { temozolomide }\end{array}$ & 2018 & Recruiting \\
\hline \multirow{2}{*}{$\begin{array}{l}\text { Universitair } \\
\text { Ziekenhuis } \\
\text { Brussel, Bart } \\
\text { Nens }\end{array}$} & \multirow{2}{*}{$\begin{array}{l}\text { MAGE-A3, MAGE-C2, } \\
\text { tyrosinase and gp100 } \\
\text { mRNA, co-electroporated } \\
\text { with TriMix (CD70, CD40L, } \\
\text { caTLR4) mRNA }\end{array}$} & Melanoma & NCT01302496 (II, single arm) & $\begin{array}{l}\text { Ipilimumab } \\
\text { (antagonistic } \\
\text { anti-CTLA-4) }\end{array}$ & 2011 & $\begin{array}{l}\text { Completed } \\
\text { [37-39] }\end{array}$ \\
\hline & & Melanoma & NCT01676779 (II, randomized) & None & 2012 & $\begin{array}{l}\text { Completed } \\
{[39]}\end{array}$ \\
\hline \multicolumn{7}{|c|}{ Direct injection of mRNA } \\
\hline \multirow[t]{7}{*}{ BioNTech SE } & $\begin{array}{l}\text { RNA-LPX with } \\
\text { NY-ESO-1, MAGE-A3, } \\
\text { tyrosinase and TPTE } \\
\text { (i.v.) }\end{array}$ & Advanced melanoma & NCT02410733 (I) & None & 2015 & $\begin{array}{l}\text { Active, not } \\
\text { recruiting } \\
{[40,41]}\end{array}$ \\
\hline & $\begin{array}{l}\text { RNA-LPX with TNBC } \\
\text { TAAs, p53 and neoAgs } \\
\text { (warehouse) (i.v.) }\end{array}$ & TNBC & NCT02316457 (I) & None & 2016 & $\begin{array}{l}\text { Active, not } \\
\text { recruiting }\end{array}$ \\
\hline & $\begin{array}{l}\text { RNA-LPX with ovarian } \\
\text { TAAs (i.v.) }\end{array}$ & Ovarian cancer & NCT04163094 (I) & $\begin{array}{l}\text { Carboplatin and } \\
\text { paclitaxel }\end{array}$ & 2019 & Recruiting \\
\hline & $\begin{array}{l}\text { RNA-LPX with prostate } \\
\text { TAAs (i.V.) }\end{array}$ & Prostate cancer & NCT04382898 (I/II) & $\begin{array}{l}\text { Cemiplimab } \\
\text { (antagonistic } \\
\text { anti-PD-1) and/or } \\
\text { goserelin acetate }\end{array}$ & 2019 & Recruiting \\
\hline & $\begin{array}{l}\text { RNA-LPX with HPV16 } \\
\text { antigens (i.v.) }\end{array}$ & $\begin{array}{l}\mathrm{HPV} 16^{+} \text {and PD-L1 } \\
\text { HNSCC }\end{array}$ & NCT04534205 (II, randomized) & $\begin{array}{l}\text { Pembrolizumab } \\
\text { (antagonistic } \\
\text { anti-PD-1) }\end{array}$ & 2020 & $\begin{array}{l}\text { Not yet } \\
\text { recruiting }\end{array}$ \\
\hline & $\begin{array}{l}\text { RNA-LPX with } \\
\text { NY-ESO-1, MAGE-A3, } \\
\text { tyrosinase and TPTE } \\
\text { (i.v.) }\end{array}$ & Melanoma & NCT04526899 (II, randomized) & Cemiplimab & 2020 & $\begin{array}{l}\text { Not yet } \\
\text { recruiting }\end{array}$ \\
\hline & $\begin{array}{l}\text { RNA-LPX with CLDN6 } \\
\text { (i.v.) }\end{array}$ & Solid tumors & NCT04503278 (I/II) & $\begin{array}{l}\text { CLDN6-specific } \\
\text { CAR-T cells }\end{array}$ & 2020 & Recruiting \\
\hline \multirow[t]{2}{*}{$\begin{array}{l}\text { Genentech Inc., } \\
\text { BioNTech SE }\end{array}$} & $\begin{array}{l}\text { RNA-LPX with tumor } \\
\text { neoAgs (i.V.) }\end{array}$ & Different solid cancers & NCT03289962 (I) & $\begin{array}{l}\text { Atezolizumab } \\
\text { (antagonistic } \\
\text { anti-PD-L1) }\end{array}$ & 2017 & Recruiting \\
\hline & & Melanoma & NCT03815058 (II, randomized) & Pembrolizumab & 2019 & Recruiting \\
\hline
\end{tabular}


Table 1 List of all active, and completed or terminated phase II/III clinical trials of mRNA vaccines in cancer therapy (Continued)

\begin{tabular}{|c|c|c|c|c|c|c|}
\hline Sponsor & $\begin{array}{l}\text { Vaccine type } \\
\text { (delivery route) }\end{array}$ & Indication & $\begin{array}{l}\text { ClinicalTrial.gov identifier } \\
\text { (phase, allocation) }\end{array}$ & Combination & Opened & Status \\
\hline $\begin{array}{l}\text { Changhai } \\
\text { Hospital; } \\
\text { Stemirna } \\
\text { Therapeutics }\end{array}$ & $\begin{array}{l}\text { mRNA encoding } \\
\text { neoAg (s.c.) }\end{array}$ & $\begin{array}{l}\text { Esophageal squamous } \\
\text { carcinoma, gastric-, } \\
\text { pancreatic- and } \\
\text { colorectal } \\
\text { adenocarcinoma }\end{array}$ & NCT03468244 (NA) & None & 2018 & Recruiting \\
\hline \multirow[t]{2}{*}{ CureVac AG } & \multirow{2}{*}{$\begin{array}{l}\text { Protamine- } \\
\text { formulated mRNA } \\
\text { (RNActive) PSA, } \\
\text { PSMA, PSCA, } \\
\text { STEAP1, PAP and } \\
\text { MUC1 (i.d.) }\end{array}$} & \multirow[t]{2}{*}{ Prostate cancer } & $\begin{array}{l}\text { NCT01817738 (I/II, } \\
\text { randomized) }\end{array}$ & None & 2012 & $\begin{array}{l}\text { Terminated } \\
{[42-44]}\end{array}$ \\
\hline & & & NCT02140138 (II, randomized) & $\begin{array}{l}\text { Radical } \\
\text { prostatectomy }\end{array}$ & 2014 & $\begin{array}{l}\text { Terminated } \\
\text { (after } \\
\text { enrollment } \\
\text { of } 35 / 36 \\
\text { patients) }\end{array}$ \\
\hline eTheRNA & $\begin{array}{l}\text { mRNA encoding } \\
\text { tyrosinase, gp100, } \\
\text { MAGE-A3, MAGE-C2, } \\
\text { and PRAME and } \\
\text { TriMix (CD40L, CD70 } \\
\text { and caTLR4) mRNA } \\
\text { (i.n.) }\end{array}$ & Melanoma & NCT03394937 (I) & None & 2018 & $\begin{array}{l}\text { Recruiting } \\
{[45]}\end{array}$ \\
\hline $\begin{array}{l}\text { Ludwig Institute } \\
\text { for Cancer } \\
\text { Research, } \\
\text { CureVac AG, } \\
\text { Böhringer } \\
\text { Ingelheim }\end{array}$ & $\begin{array}{l}\text { RNActive encoding } \\
\text { NY-ESO-1, MAGE-C1, } \\
\text { MAGE-C2, TPBG, } \\
\text { survivin, MUC1 (i.d.) }\end{array}$ & Meatastatic NSCLC & NCT03164772 (I/II) & $\begin{array}{l}\text { Durvalumab } \\
\text { (antagonistic } \\
\text { anti-PD-L1), } \\
\text { Tremelimumab } \\
\text { (antagonistic } \\
\text { anti-CTLA-4) }\end{array}$ & 2017 & Recruiting \\
\hline $\begin{array}{l}\text { Merck Sharp \& } \\
\text { Dohme Corp. }\end{array}$ & $\begin{array}{l}\text { LNP-formulated } \\
\text { mRNA encoding } \\
\text { different KRAS } \\
\text { mutations (i.m.) }\end{array}$ & $\begin{array}{l}\text { KRAS-mutant NSCLC, } \\
\text { colorectal cancer, } \\
\text { pancreatic } \\
\text { adenocarcinoma }\end{array}$ & NCT03948763 (I) & Pembrolizumab & 2019 & Recruiting \\
\hline \multirow{2}{*}{$\begin{array}{l}\text { ModernaTX Inc., } \\
\text { Merck Sharp \& } \\
\text { Dohme Corp. }\end{array}$} & \multirow{2}{*}{$\begin{array}{l}\text { Lipid-formulated } \\
\text { mRNA encoding } \\
\text { neoAg (i.m.) }\end{array}$} & Solid tumors & NCT03313778 (I) & Pembrolizumab & 2017 & $\begin{array}{l}\text { Recruiting } \\
{[46]}\end{array}$ \\
\hline & & Melanoma & NCT03897881 (II, randomized) & Pembrolizumab & 2019 & Recruiting \\
\hline $\begin{array}{l}\text { University of } \\
\text { Florida }\end{array}$ & $\begin{array}{l}\text { Lipid-formulated } \\
\text { mRNA with tumor } \\
\text { and LAMP-fused } \\
\text { HCMV pp65 TAA } \\
\text { mRNA (i.v.) }\end{array}$ & Adult glioblastoma & NCT04573140 (I) & None & 2020 & $\begin{array}{l}\text { Not yet } \\
\text { recruiting }\end{array}$ \\
\hline
\end{tabular}

From ClinicalTrial.gov (keywords: cancer, mRNA, vaccine) on Nov 1, 2020 and PubMed literature search. AML acute myeloid leukemia, ca constitutively active, CLDN6 claudin-6, CTLA-4 cytotoxic T-lymphocyte-associated protein 4, GBM glioblastoma multiforme of brain, GM-CSF granulocyte-macrophage colony stimulating factor, HCMV human cytomegalovirus, HNSCC head and neck squamous cell carcinoma, HPV human papilloma virus, $h T E R T$ telomerase reverse transcriptase, i.d. intradermal, i.m. intramuscular, i.n. intranodal, i.v. intravenous, IDO indoleamine-pyrrole 2,3-dioxygenase, IKKb inhibitor of nuclear factor kappa-B kinase subunit beta, LAMP lysosome-associated membrane glycoprotein, MAGE melanoma-associated antigen, MUC1 mucin-1, neoAg neoantigen, NY-ESO-1 New York esophageal squamous cell carcinoma-1, NSCLC non-small-cell lung cancer, PAP prostatic acid phosphatase, $P D-1$ programmed cell death protein $1, P D-L 1$ Programmed cell death ligand 1, PRAME melanoma antigen preferentially expressed in tumors, PSA prostate-specific antigen, PSCA prostate stem cell antigen, PSMA prostatespecific membrane antigen, RCC renal cell carcinoma, RNActive Protamine-formulated mRNA, RNA-LPX liposome-formulated mRNA, s.c. subcutanous, STEAP 6transmembrane epithelial antigen of prostate, TAA tumor-associated antigen, $t d$ tetanus-diphtheria toxoid, TLR toll-like receptor, TNBC triple-negative breast cancer, TPBG trophoblast glycoprotein, TPTE transmembrane phosphatase with tensin homology, Trp2 tyrosinase-related protein-2, WT1 Wilm's tumor protein 1

enhanced survival in comparison to non-immuneresponders ( 14 vs. 6 months). As the mRNA is extracted from the individual patient's tumor, feasibility depends on sample availability and quality. Vaccine production is therefore highly variable and sometimes impossible. Within the extracted mRNA, truly cancer-associated antigen encoding mRNAs represent a very small fraction. A low number of relevant epitopes needs to compete with the majority of irrelevant peptides for presentation on $\mathrm{MHC}$ molecules for $\mathrm{T}$-cell priming. In vitro mRNA amplification attempting to increase the abundance of all mRNA species in bulk preparations including those representing potential tumor rejection antigens, may even promote under-representation or loss of immunogenic antigens or epitopes in the process [54].

Another approach is to resort to defined TAAs and generate synthetic mRNA for ex vivo DC transfection, as has been done with prostate-specific antigen (PSA) [55], carcinoembryonic antigen (CEA) [56, 57], gp100/tyrosinase [58-60], human telomerase reverse transcriptase 
(hTERT) [61] and Wilms' tumor 1 (WT1) antigen [27, 62]. TAA mRNA DC vaccines exhibited good safety profiles in phase I and I/II clinical trials without serious adverse effects, such as autoimmunity, and did not show dose-limiting toxicity. In a phase II clinical study (NCT00965224), patients with acute myeloid leukemia (AML) in remission were vaccinated with WT1 mRNAelectroporated DCs [27]. Prevention or delay of relapse was observed in $43 \%$ of patients and the five-year overall survival of the vaccinated patients compared favorably to historic controls.

In a randomized phase II clinical trial (NCT01446731), a DC vaccine with mRNA encoding PSA, prostatic acid phosphatase (PAP), survivin and hTERT failed to significantly increase the disease-specific survival of docetaxeltreated, castration-resistant prostate cancer patients (docetaxel: 21.9 months, docetaxel and DC vaccination: 25.1 months) [34]. TAA-specific T-cell responses were present in 9 of the 18 combination therapy-treated patients, of which three were de novo.

In 78 melanoma patients with resected regional lymph node metastases (NCT00940004, NCT01530698, NCT02285413, NCT00243529), vaccination with gp100and tyrosinase-mRNA loaded DC vaccines as an adjuvant treatment showed a favorable safety profile and induced tumor-specific $\mathrm{T}$-cell responses in $71 \%$ of the patients [63]. The overall survival of DC-vaccinated patients was doubled as compared to that of 209 matched controls (63.6 months vs. 31.0 months).

Generally speaking, T-cell responses induced by mRNA-loaded DC vaccines have been rather weak, which may contribute to the low clinical efficacy. DC differentiation, maturation and antigen loading directly impact DC homing and $\mathrm{T}$ cell co-stimulation (reviewed in $\mathrm{Gu}$ et al. [64]), and are targets for further improvement of this approach.

\section{Engineering DC antigen presentation}

Cognate T-cell help is a critical factor that determines the extent of vaccine-induced $\mathrm{T}$-cell responses. This requires the vaccine antigen to be presented on MHC class II molecules of the DC. mRNA transfected into DCs undergoes cytoplasmic translation, enters the endogenous processing compartment and is therefore presented on MHC class I rather than MHC class II molecules. Several strategies have been followed to enhance MHC class II antigen presentation by routing the antigen through lysosomal compartments, such as fusion of the vaccine antigen to lysosome-associated membrane proteins (LAMPs) $[65,66]$, or to the MHC class I cytoplasmic and transmembrane domain [67]. Fusion of a lysosomal targeting signal (LAMP-1) to CEA in a chimeric mRNA (CEA/LAMP-1) enhanced the expansion of CEA-specific $\mathrm{CD} 4^{+} \mathrm{T}$-cell responses and led to a more potent CEA-specific CTL response in vitro [68]. CEA LAMP mRNA-transfected DC vaccines were evaluated in phase I studies in patients with newly diagnosed glioblastoma multiforme (NCT02529072, NCT00626483, NCT00639639) [32, 33, 69, 70], which suggested prolongation of overall survival as compared to nontransfected DC vaccines or historical controls [33]. Four ongoing phase II clinical trials are evaluating CEA/ LAMP-1 mRNA engineered DC vaccines in glioblastoma patients in combination with tetanus toxoid preconditioning to enhance DC migration, granulocytemacrophage colony-stimulating factor (GM-CSF), and other drugs, such as basiliximab (antagonistic anti-CD25 monoclonal antibody $(\mathrm{mAb})$ ), varilumab (agonistic anti$\mathrm{CD} 27 \mathrm{mAb}$ ) or temozolomide (NCT02366728, NCT03927222, NCT03688178, NCT02465268).

\section{Co-stimulatory ligands and receptors}

As ssRNA and dsRNA trigger TLR activation, pulsing of DCs with mRNA provides a maturation signal irrespective of the biological activity of the encoded antigen. Several strategies aim to further improve the T-cell priming capacity of tumor-antigen loaded DC vaccines. These include co-transfection with immunostimulatory ligands and receptors for enhanced DC maturation and T-cell co-stimulation, which can be introduced by mRNA. In preclinical studies, DC co-transfection of cancer antigens with OX40 ligand (OX40L), 4-1BB ligand (4-1BBL), glucocorticoid-induced tumor necrosis factor receptor (GITR) ligand (GITRL), CD40 ligand (CD40L), constitutively active (ca)CD40 or inducible $\mathrm{T}$ cell co-stimulatory ligand (ICOSL) mRNA improved DC co-stimulation and resulted in enhanced $\mathrm{T}$-cell priming [71-76]. One of the most clinically advanced DC vaccines is Rocapuldencel$\mathrm{T}$, an autologous tumor mRNA-transfected $\mathrm{DC}$ vaccine co-transfected with CD40L mRNA [28, 29]. In a phase III trial with 462 metastatic RCC (mRCC) patients (NCT01582672), Rocapuldencel-T failed to improve the overall survival of sunitinib-treated $\mathrm{mRCC}$ patients. Cotransfecting TAA mRNA-loaded DC vaccines with CD40L, CD70 and caTLR4 mRNA (TriMix) represents an alternative approach [77-79]. Superior T-cell priming capacity was observed by $\mathrm{T}$-cell stimulation with TriMix-transfected DCs compared to that induced by irrelevant mRNA-transfected immature DCs, or by DCs matured in culture supplemented with cytokines (IL-1 $\beta$, IL-6, tumor necrosis factor (TNF) $\alpha$, and prostaglandin E2 (PGE2)) [77]. In a single-arm phase II clinical study, TriMix-DCs, transfected with TriMix and four TAAs (melanoma-associated antigen (MAGE)-A3, MAGE-C2, tyrosinase, or gp100) fused to an MHC class II targeting signal, plus the $\mathrm{mAb}$ ipilimumab (blocking the immune checkpoint cytotoxic T-lymphocyte-associated protein 4 (CTLA-4)) were combined in 39 pretreated advanced 
melanoma patients (NCT01302496) [37]. The combination was well tolerated and after a median follow-up of 36 months, eight complete and seven partial responses were observed. T-cell responses were detected in 12 of 15 patients by IFN $\gamma$ enzyme-linked immunospot (ELISpot) [38]. The study lacked a direct comparison of TriMix-DCs and ipilimumab against ipilimumab alone.

\section{Co-stimulatory cytokines}

mRNA-encoded cytokines are another class of molecules used to enhance DC maturation and T-cell priming capacity. In the context of autologous DC vaccines loaded with whole tumor mRNA preparations or with synthetic TAA-encoding mRNA, co-transfection with cytokineencoding mRNA, such as GM-CSF, IL-12 and IL-15, was explored [80-84]. Co-transfection of GM-CSF mRNA into tumor mRNA-loaded DCs significantly enhanced the anti-tumor efficacy of DC vaccines in CT26 tumor-bearing mice, which was associated with increased cytotoxicity of bulk splenocytes against CT26 tumor cells in vitro [80]. In another study, co-delivery of IL-12 mRNA enhanced the ex vivo migratory and immunostimulatory capacity of healthy donor-derived human DCs transfected with melanoma antigen recognized by $T$ cells (MART)-1 [81]. Proliferation, effector function and memory potential of MART-1-specific $\mathrm{CD}^{+} \mathrm{T}$ cells were significantly enhanced by co-culture with IL-12 and MART-1 mRNA-transfected DCs compared to MART-1 mRNA-transfected DCs alone.

\section{mRNA-based direct cancer vaccines}

The direct injection of mRNA is an alternative to DC vaccines and circumvents the necessity of DC isolation, ex vivo cultivation and re-infusion. Injected mRNA is taken up by local cells, including APCs, and translocates to the cytoplasm for translation. Various mRNA vaccines are currently being evaluated, using different nanoparticle formulations, delivery routes and structural backbones, of which the most advanced candidates are summarized below.

\section{Non-formulated $m R N A$ vaccines}

Non-formulated or "naked" mRNA administered intradermally or into lymph nodes (intranodally) has been shown to prime T-cell responses in mice [85-88] and humans $[45,89,90]$. The rationale for intranodal injection is to deliver the vaccine directly into the area of Tcell priming for uptake by resident DCs. The major uptake mechanism of naked mRNA by immature DCs in lymph nodes [91] and in the dermis [92] is macropinocytosis. The feasibility and safety of naked mRNA vaccines was first demonstrated in a phase I/II trial in 15 metastatic melanoma patients using intradermally injected autologous tumor mRNA and GM-CSF [93]. In five of 13 evaluable patients, enhanced antigen-specific $\mathrm{CD}^{+}$and $\mathrm{CD}^{+}{ }^{+}$-cell responses in ex vivo expanded PBMC were detected by intracellular IFN $\gamma$ staining upon re-stimulation with tumor mRNA-transfected PBMC. Vaccine-induced humoral responses were analyzed by incubating allogenic melanoma cell lines with plasma samples taken before or during the therapy followed by flow cytometry analysis to detect cell-bound IgG antibodies. Upon vaccination, an increase in the amount of tumor-cell specific IgG antibodies was observed in the plasma of four out of the 13 patients. Objective responses were not apparent in this trial. In a phase I/II clinical study with 30 stage IV RCC patients, intradermal administration of naked mRNA encoding mucin 1 (MUC1), CEA, human epidermal growth factor receptor-2 (HER-2)/neu, telomerase, survivin and MAGE-A1 combined with GM-CSF was well tolerated and associated with stable disease in 15 patients and one partial response [90]. Antigen-specific T-cell responses were observed by IFNY ELISpot or chromium-release cytotoxicity assays in 12 out of 17 patients.

In 2012, a phase I study of 29 advanced melanoma patients was initiated, which proved that intranodal injection of mRNA is both feasible and safe (NCT01684241) (unpublished results). Vaccination induced either de novo or expanded existing T-cell responses against the vaccine-encoded antigens New York esophageal squamous cell carcinoma-1 (NY-ESO-1) and tyrosinase in six out of 13 evaluable patients. New lesions occurred in only eight of the 29 patients during the course of the study. In another phase I study of 20 melanoma patients (NCT03394937), intranodal injection of tyrosinase, gp100, MAGE-A3, MAGE-C2, and melanoma antigen preferentially expressed in tumors (PRAME)-encoding mRNA together with TriMix mRNA was well tolerated. As observed by IFNy ELISpot and intracellular cytokine staining, T-cell responses against at least one TAA were induced in 35\% of patients [45].

Mutated neoantigens are promising vaccine targets as they are abundant in many tumor types and highly tumor-specific (reviewed in Vormehr et al. [94]). Neoantigen-specific $\mathrm{T}$ cells are likely not subject to central tolerance and have a higher likelihood to induce high-affinity $\mathrm{T}$-cell responses, while TAAs come with the challenge of breaking tolerance. However, as each single tumor has its unique profile of mutations, the full potential of mutated neoantigens as an ideal source for vaccine antigens can only be leveraged in the context of individualized vaccines, with each and every patient being administered their personal set of mutated epitopes. As mRNA vaccines can be produced fast and costeffectively, they are particularly suited for the purpose of "on demand" vaccine design and manufacturing. Intranodal administration of a neoantigen-specific mRNA 
vaccine, comprising 20 patient-specific mutations, was investigated in a phase I clinical trial in stage III and IV melanoma patients (NCT02035956) [89]. Neoantigenspecific mRNA vaccines induced $\mathrm{CD} 4^{+}$and $\mathrm{CD} 8^{+} \mathrm{T}$-cell responses against multiple vaccine neoepitopes in 13 evaluable melanoma patients. Objective responses were observed and the cumulative rate of recurrences was significantly reduced by vaccination, resulting in a sustained progression-free survival. The vaccine was well tolerated.

\section{Formulated $m R N A$ vaccines}

Nanoparticulate formulations protect mRNA from extracellular RNases and improve uptake by APCs in vivo. Formulations typically contain polymers, such as protamine, or cationic and ionizable lipids with or without polyethylene glycol (PEG) derivatives to enable complexing with mRNA via electrostatic interactions and condensing of the RNA molecules (reviewed in Zeng et al. [95]).

One of the mRNA formulations in advanced clinical development is based on protamine, a polycationic peptide that complexes negatively charged mRNA for intradermal delivery [42-44, 96-100]. In mice, protamineformulated mRNA is taken up by leukocytes and nonleukocytes in the skin, including APCs that migrate to the draining lymph node, express and present the encoded protein and induce $\mathrm{T}$-cell responses [96]. The safety and feasibility of a protamine-formulated mRNA vaccine encoding MART-1, tyrosinase, gp100, MAGEA1, MAGE-A3 and survivin was demonstrated in 21 metastatic melanoma patients (NCT00204607) [99]. The mRNA vaccine was injected intradermally with GM-CSF either alone or in conjunction with keyhole limpet hemocyanin as adjuvants [101]. Antigen-specific T cell responses in ex vivo expanded PBMC were detected by intracellular IFN $\gamma$ staining after re-stimulation with irradiated, autologous PBMC transfected with TAA mRNA. Vaccination was associated with an increase in the number of antigen-specific $\mathrm{CD}^{+}$and $\mathrm{CD}^{+} \mathrm{T}$ cells in two of four immunologically evaluable patients. One complete response occurred in seven patients with measurable disease. In addition, a vaccine encoding six protamineformulated prostate cancer-specific antigens (PSA, prostate-specific membrane antigen (PSMA), prostate stem cell antigen (PSCA), 6-transmembrane epithelial antigen of prostate (STEAP), PAP and MUC1) was investigated in a phase I/II trial in patients with asymptomatic or minimally symptomatic metastatic castrateresistant prostate cancer (NCT01817738) [42-44]. The vaccine was well tolerated. In the phase I part, vaccineinduced antigen-specific $\mathrm{T}$-cell responses were shown in 26 of 33 patients by ex vivo IFNy ELISpot assay, intracellular cytokine and tetramer flow cytometry [44]. In the randomized, placebo-controlled phase II part of the study $(n=197)$ [43], the vaccine failed to improve overall survival and progression-free survival. A vaccine derived from the same protamine-formulated mRNA platform encoding five tumor-associated antigens (NYESO-1, MAGE-C1, MAGE-C2, survivin and trophoblast glycoprotein (TPBG)) was further evaluated in a phase I/ IIa dose-escalation trial in seven patients with locally advanced and 39 patients with metastatic non-small-cell lung cancer (NSCLC) and controlled disease after firstline therapy (NCT00923312) [100]. The vaccine was well-tolerated and induced $\mathrm{T}$-cell responses against one or more antigens in $63 \%$ of evaluable patients. The median overall survival, however, was not improved by vaccine monotherapy compared to that typically seen with maintenance chemotherapy. An ongoing phase I/II trial is currently evaluating this vaccine, with the addition of the antigen MUC1 in combination with either the antagonistic anti-programmed death-ligand 1 (PD-L1) antibody durvalumab or durvalumab plus the antagonistic anti-CTLA-4 antibody tremelimumab in patients with metastatic NSCLC (NCT03164772).

A major limitation of local administration is that only the injected or the draining lymph nodes are accessed and participate in antigen-specific T-cell priming. Other formulations are required for intravenous administration to deliver mRNA to secondary lymphoid organs bodywide, including the spleen as the largest agglomeration of immune cells. Formulation technologies developed for intravenous administration not only protect RNA integrity, but also promote its targeted expression in lymph node-resident DCs.

mRNA lipoplexes (RNA-LPX) are based on cationic liposomes as broadly used for transfection reagents in vitro [102]. Specific delivery of nanoparticles to APCs and improved uptake for presentation of epitopes derived from the encoded antigens can be achieved by decorating such particles with targeting moieties, such as antibodies, single chain variable fragments $(\mathrm{scFv})$ fragments and small molecules binding DEC-205, mannose receptors and C-type lectin domain family 9 (CLEC9A) (reviewerd in Phuha et al. [103]; [104, 105]). Alternatively, RNA-LPX can be modified to have a negative net charge when prepared by molar excess of negatively charged mRNA, or by shielding positive surface charges with PEG. mRNA-LPX with a negative net charge are subject to specific uptake by APCs in vivo without the need for targeting moieties (reviewed in Guan et al. [106]).

Intravenously administered negatively charged to nearneutral RNA-LPX vaccines have been shown in mice to target APCs resident in lymphoid organs, including the spleen, lymph nodes and bone marrow, while inducing strong local (cell-specific activation) and systemic 
(proinflammatory cytokine abundance in the circulation) type I IFN-dominated immune modulation [40]. In several mouse tumor models, RNA-LPX vaccines induce strong effector and memory T-cell responses directed against the encoded TSAs or TAAs, and mediate tumor growth control or rejection, and improve survival [40, 107-109]. In a phase I clinical trial (NCT02410733), 119 melanoma patients were vaccinated with an RNA-LPX vaccine encoding the four melanoma TAAs MAGE-A3, transmembrane phosphatase with tensin homology (TPTE), NY-ESO-1 and tyrosinase [40, 41]. In the subset of antagonistic anti-programmed cell death protein-1 (PD-1) antibody-experienced patients with evaluable disease at baseline $(n=25)$, vaccination alone mediated one metabolic complete response, three partial responses and seven cases of stable disease. In combination with anti-PD-1 antibodies (pembrolizumab or nivolumab, $n=$ 17), six partial responses and two cases of stable disease were observed. RNA-LPX vaccine-induced $\mathrm{CD}^{+}$and $\mathrm{CD}^{+} \mathrm{T}$-cell responses were observed in the majority of patients reaching up to low double-digit percentages of total circulating $\mathrm{CD}^{+} \mathrm{T}$ cells. A randomized phase II study will investigate this melanoma TAA-specific RNALPX vaccine in combination with the antagonistic antiPD-1 antibody cemiplimab (NCT04526899). The same platform encoding other tumor type specific TAAs is being evaluated in various phase I and I/II clinical trials in patients with triple negative breast cancer (TNBC; NCT02316457), ovarian cancer (NCT04163094) and prostate cancer (NCT04382898).

Moreover, several clinical trials are testing this intravenous RNA-LPX technology in conjunction with TSAs, which are expected to be less compromised by central immune tolerance. One example is a human papilloma virus (HPV)16 E6 and E7 mRNA-encoding RNA-LPX vaccine, which is being evaluated in a randomized phase II trial in combination with pembrolizumab in patients with $\mathrm{HPV} 16^{+}$and PD-L $1^{+}$head and neck squamous cell carcinoma (HNSCC) (NCT04534205). Another example is the so-called individualized neoantigen-specific immunotherapy (iNeST) program, which treats each patient with their 'on-demand' manufactured individualized set of cancer mutations. This truly personalized treatment approach is being tested in various tumor types and treatment lines in the phase I and II studies NCT03289962, NCT03815058, and NCT04486378.

The same RNA-LPX vaccine platform was utilized to expand chimeric antigen receptor (CAR)-engineered $\mathrm{T}$ cells against claudin 6 (CLDN6), a carcinoembryonic cell surface antigen, in mice [110]. Vaccination with CLDN6-encoding RNA-LPX resulted in the expression of CLDN6 on splenic DCs and macrophages in vivo and increased the proportion of proliferating CLDN6-CAR-T cells after adoptive transfer. Subtherapeutic doses of
CLDN6-CAR-T cells were expanded by the CLDN6 RNA-LPX vaccine, resulting in regression of subcutaneous $\mathrm{CLDN6}^{+}$Lewis lung tumors. Safety and efficacy of this concept are currently being evaluated in a phase I/II clinical study in patients with solid cancers (NCT04503278).

Lipid nanoparticles (LNPs) are mRNA formulations based on a mixture of cholesterol, ionizable and helper lipids, and PEG-derivatives [106]. Intramuscularly administered RNA-LNPs have recently gained attention, as this is the format of the first two SARS-CoV-2 vaccines to be approved, based on their demonstration of compelling efficacy in COVID-19 protection [22, 111-117], which was in line with previous preclinical and clinical data showing induction of strong antigen-specific immune responses against other infectious diseases [118-120]. Both BNT162b2 and mRNA-1273 contain $\mathrm{N}^{1}$-methylpseudouridine-modified mRNA with blunted innate immune modulatory activity to promote potent $\mathrm{T}_{\mathrm{H}} 1$, $\mathrm{T}$ follicular helper and germinal center $\mathrm{B}$ cell responses for the induction of neutralizing antibodies as part of the multi-effector immune response [115, 121, 122].

In the cancer therapeutic field, intramuscularly administered, LNP-formulated nucleoside-modified mRNA vaccines encoding 20 patient-specific mutated neoepitopes are currently being evaluated in combination with pembrolizumab in patients with solid cancer (NCT03313778, phase I) and melanoma (NCT03897881, randomized phase II). Data from a recent phase I clinical trial in four gastrointestinal cancer patients (NCT03480152) suggest that vaccination with neoantigen-specific RNA-LNP is safe and induces mutation-specific T-cell responses [123] with no objective clinical responses observed yet in the limited number of patients tested.

Besides the clinically explored mRNA formulations discussed above, a plethora of different in vivo DCtargeting mRNA nanoparticles are under development. A recent study analyzed over 1000 mRNA lipid formulations for transfection efficacy. A subset of these were tested for in vivo protein production, APC maturation in local lymph nodes, induction of $\mathrm{T}$ and $\mathrm{B}$ cell responses in naïve, and anti-tumor efficacy of Trp2, OVA and E7encoding mRNA lipid formulations in B16, B16-OVA and TC-1 tumor-bearing mice [124]. The formulations performing best shared a common structure involving an unsaturated lipid tail, a dihydroimidazole linker and a cyclic amine head group and mediate APC maturation by signaling through the STING pathway. Insights such as these will promote rational approaches for formulation development.

\section{mRNA-encoded antigen receptors}

Another immunotherapy approach in cancer is based on the redirection of $\mathrm{T}$ cells against tumor cells by stable 
integration of tumor-specific antigen receptors, either with $\mathrm{T}$ cell receptors (TCRs) which recognize MHCpresented epitopes from both intra- and extracellular antigens, or CARs which bind to tumor surface antigens and are MHC-independent. T cells are then expanded in cell culture systems. Patients are treated with a lymphodepleting chemotherapy regimen prior to adoptive cell transfer (ACT) of such engineered cell products to improve engraftment.

In the ACT field, CD19-directed CAR-T cells are the most advanced. Several products have been market authorized for the treatment of B-cell leukemia and lymphoma $[125,126]$ based on response rates of over $80 \%$, half of which were complete responses. Usually retro- or lentiviral technologies are applied to engineer antigenreceptor expressing cells. Stably transduced CAR-T cells are highly potent and are living drugs, the efficacy of which is associated with their capability to persist. When developing CAR-T cells against new antigens that are not yet vetted clinically for target safety, transient expression of an mRNA-encoded CAR may be riskmitigating. Also, in contrast to viral transduction, mRNA does not pose the risk of genomic integration of the transgene and malignant transformation. mRNA transfection further allows the co-delivery of additional mRNAs for concomitant manipulation of lymphocytes, such as immunostimulatory cytokines [127], chemokine receptors or adhesion molecules for targeted migration [128-131], or Cas9-mediated genome editing [132].

\section{Generating CAR-T cells with mRNA}

Electroporation of mRNA CARs is a practical and scalable method accomplishing lymphocyte transfection rates of more than $90 \%$ without affecting the viability of the cell product, and is used in the vast majority of studies [133-136]. mRNA electroporation results in CAR expression on the surface of $\mathrm{T}$ cells for around 7 days [137-140] and CARs internalized upon target cell encounter are not restored [139, 141-144]. The molecular structure of the CAR construct (e.g., co-stimulatory domains) may impact the level and duration of expression [145-148]. While the level and persistence of CAR expression correlate positively with potency of killing, high CAR expression was shown in vitro to favor activationinduced cell death (AICD) [138], and high amounts of mRNA input can affect viability [149]. Optimization of structural elements including the $5^{\prime}$ cap, UTRs and poly(A) tail $[150,151]$ improves CAR expression levels and duration, and may circumvent the need for high mRNA input amounts. In addition, dsRNA removal and $\mathrm{N}^{1}$-methylpseudouridine modification have been shown to enhance CAR expression and result in more functional CAR-T cells [152], but have not yet been applied in clinical mRNA CAR studies.
mRNA CAR-T cells must be administered repeatedly, in contrast to classical CAR-T cells which constitutively express the CAR. Consequently, mRNA CAR-T cells are produced in large quantities and cryopreserved in batches that can be thawed for each treatment cycle. GMP-compliant protocols for the large-scale manufacturing of mRNA CAR-T cells have been established $[153,154]$, and freezing mRNA CAR-T cells was demonstrated not to negatively affect their function [136, 138, $145,148]$. For the treatment of solid tumors, intratumoral injection is a way to prevent $\mathrm{T}$ cells from losing CAR expression before reaching the tumor cells [143]. Clinical development programs need to implement proper follow-up of CAR T cell persistence kinetics to develop treatment schedules and define dosing intervals, which may differ depending on the preparation of the engineered cell product.

\section{Preclinical and clinical testing of mRNA-encoded CARs} Early studies with TCRs specific for NY-ESO-1, MART1 or p53 [133] and a CAR directed against CD19 [155] showed that mRNA-transfected $\mathrm{T}$ cells efficiently lyse antigen-expressing tumor cells. First evidence for antitumor effects in vivo came from PBLs transfected with mRNA encoding a HER-2/neu-specific CAR in an ovarian cancer xenograft model [134]. Clinical phase I studies explored mRNA CAR-T cells directed against various antigens (Table 2). Treatment with mRNA CAR-T cells targeting CD19 was shown to be well tolerated in pilot phase I studies in pediatric (NCT02624258) and adult (NCT02277522) patients with classical Hodgkin lymphoma. Patients not only underwent lymphodepleting chemotherapy prior to CAR-T cell infusion, but also in between CAR- $T$ cell cycles to deplete $T$ cells that had lost CAR expression, using a lymphodepletion protocol that had enhanced the efficacy of repeated mRNA CAR$\mathrm{T}$ cell delivery in preclinical models [162]. Two treatment cycles were conducted, each representing three CAR-T cell infusions 2 to 3 days apart with lymphodepletion 1 or 4 days before each cycle. One patient of four evaluable patients experienced a complete response. Assessment of CAR mRNA transcripts in the blood of this patient 2 days after each adoptive transfer confirmed the presence of the infused cells. In the remaining patients, no CAR-T cells were detected in the majority of samples taken 2 days after infusion [163].

Two phase I studies (NCT01355965, NCT01897415) were initiated based on the observation that repeated injection of mesothelin-directed [165] mRNA CAR-T cells prevented tumor outgrowth in solid and disseminated mesothelioma xenograft models [150]. Preliminary analyses of eight out of 34 patients showed that this approach is well tolerated, with one exception: One patient experienced anaphylactic shock, most likely resulting 
Table 2 List of all active, completed or terminated clinical trials of mRNA CAR-T cells in cancer therapy

\begin{tabular}{|c|c|c|c|c|c|c|}
\hline Sponsor & Therapy & Indication & $\begin{array}{l}\text { ClinicalTrial.gov } \\
\text { identifier } \\
\text { (phase) }\end{array}$ & Combination & Opened & Status \\
\hline Cartesian Therapeutics & $\begin{array}{l}\text { BCMA CAR-T } \\
\text { cells (Descartes- } \\
\text { 08) }\end{array}$ & $\begin{array}{l}\text { Multiple } \\
\text { myeloma }\end{array}$ & NCT03448978 (I) & $\begin{array}{l}\text { Fluodarabine and } \\
\text { cyclophosphamide } \\
\text { pretreatment }\end{array}$ & 2018 & Recruiting [156] \\
\hline $\begin{array}{l}\text { The Third Affiliated Hospital } \\
\text { of Guangzhou Medical } \\
\text { University }\end{array}$ & $\begin{array}{l}\text { NKG2D-ligand } \\
\text { targeting CAR-NK } \\
\text { cells }\end{array}$ & Solid tumors & NCT03415100 (I) & IL-2 & 2018 & Unknown [157] \\
\hline \multirow[t]{7}{*}{ University of Pennsylvania } & $\begin{array}{l}\text { Mesothelin CAR- } \\
\mathrm{T} \text { cells }\end{array}$ & $\begin{array}{l}\text { Malignant } \\
\text { pleural } \\
\text { mesothelioma }\end{array}$ & NCT01355965 (I) & None & 2011 & Completed $[158,159]$ \\
\hline & & $\begin{array}{l}\text { Metastatic } \\
\text { PDAC }\end{array}$ & NCT01897415 (I) & None & 2013 & Completed $[159,160]$ \\
\hline & $\begin{array}{l}\text { c-MET CAR-T } \\
\text { cells }\end{array}$ & $\begin{array}{l}\text { Metastatic } \\
\text { breast cancer, } \\
\text { TNBC }\end{array}$ & NCT01837602 (I) & None & 2013 & Completed [161] \\
\hline & & $\begin{array}{l}\text { Melanoma, } \\
\text { breast cancer }\end{array}$ & NCT03060356 (I) & None & 2016 & $\begin{array}{l}\text { Terminated (lack of } \\
\text { funding) }\end{array}$ \\
\hline & CD19 CAR-T cells & $\begin{array}{l}\text { Hodgkin } \\
\text { lymphoma }\end{array}$ & NCT02277522 (I) & $\begin{array}{l}\text { Interval } \\
\text { cyclophosphamide } \\
{[162]}\end{array}$ & 2014 & $\begin{array}{l}\text { Terminated (inability to } \\
\text { meet enrollment goal) } \\
\text { [163] }\end{array}$ \\
\hline & & & NCT02624258 (I) & $\begin{array}{l}\text { Interval } \\
\text { cyclophosphamide } \\
\text { [162] }\end{array}$ & 2015 & $\begin{array}{l}\text { Terminated (PI's } \\
\text { decision) [163] }\end{array}$ \\
\hline & $\begin{array}{l}\text { CD123 CAR-T } \\
\text { cells }\end{array}$ & $\begin{array}{l}\text { Relapsed or } \\
\text { refractory AML }\end{array}$ & NCT02623582 (I) & $\begin{array}{l}\text { Cyclophosphamide } \\
\text { pretreatment }\end{array}$ & 2015 & $\begin{array}{l}\text { Terminated (lack of } \\
\text { funding) [164] }\end{array}$ \\
\hline
\end{tabular}

From ClinicalTrial.gov (keywords: cancer, mRNA, CAR) on Nov 1, 2020 and PubMed literature research. $A M L$ acute myeloid leukemia, $B M C A$ B cell maturation antigen, CAR chimeric antigen receptor; CMET protein kinase Met; IL interleukin, NK natural killer, NKG2D Natural killer group 2D, PDAC pancreatic ductal adenocarcinoma; protein kinase Met, TNBC triple-negative breast cancer

from the induction of IgE antibodies against murine sequences in the CAR construct [158]. One patient with advanced malignant pleural mesothelioma experienced a partial response after three infusions and a second patient with metastatic pancreatic cancer had stable disease and a $40 \%$ decrease of tumor cells in ascites after receiving eight intravenous infusions followed by two intratumoral injections [159]. CAR transcripts were detectable in the blood of the patients for up to 3 days after infusion. CAR-T cells persisted longer in ascites and the primary tumor of the pancreatic cancer patient, where transcripts were detectable 6 days after intravenous or 13 days after intratumoral injection, respectively. In six other individuals with pancreatic cancer, stable disease occurred in two patients, and a third patient experienced a partial metabolic response of the target lesion [160].

In AML, lineage markers used as target antigens are expressed by hematopoietic stem cells and myeloid progenitor cells $[140,166]$. Targeting antigens such as CD33 or CD123 may cause hematologic toxicity, which is less manageable than the B-cell depletion induced by targeting of CD19. Two studies showed eradication of AML xenografts assessed by CD33 [140] or CD123 [167] mRNA CAR $\mathrm{T}$ cells in preclinical mouse models. The self-inactivation of CD123 CAR expression allowed the subsequent recovery of the myeloid compartment by bone marrow transplantation. This approach proceeded to clinical testing in relapsed or refractory AML (NCT02623582). However, in the seven patients who received up to six infusions of CD123 mRNA CAR-T cells, no clinical benefit was observed [164].

mRNA CAR-T cells targeting protein kinase Met (c-Met) are in clinical development for the treatment of breast cancer and melanoma (NCT01837602, NCT03060356) [161], and B-cell maturation antigen (BCMA)-specific mRNA CAR-T cells are being developed as a treatment option for multiple myeloma (NCT03448978) [156].

mRNA CARs are also used for retargeting of $\gamma \delta$ T cells [168, 169], NKT cells [170] and NK cells [135, 171, 172]. Besides the classical CAR construct containing an $\mathrm{scFv}$ as a targeting moiety, CARs featuring the extracellular domain of natural killer group 2D (NKG2D) have been engineered to recognize tumor cells that express high levels of NKG2D ligands. This approach showed promising results in preclinical studies [157]. In a clinical phase I study using CAR-NK cells (NCT03415100), preliminary signals of clinical activity were observed in three evaluated colorectal cancer patients: two experienced reduction of tumor cells in ascites and stable disease, a third patient had a complete metabolic response of a liver lesion [157]. 


\section{mRNA-encoded antibodies}

mRNA is also being explored for delivery of full IgG $\mathrm{mAbs}$ or scaffolds, including engineered bispecific antibody fragments, and addresses pharmacokinetic (e.g., short half-life, fast clearance) as well as manufacturing challenges (e.g., aggregates) to accelerate clinical development.

mAbs are an established treatment modality in cancer and are used for targeting of tumor cells and for the modulation of immune cell responses. Most of the approved recombinant mAbs are administered intravenously to achieve systemic exposure.

Established standard-of-care mAbs are obvious starting points to explore $\mathrm{mAb}$-encoding mRNA in conjunction with liver-targeting formulations for high protein production in liver-resident cells and release of the protein into the circulation. Rituximab, targeting CD20, was the first $\mathrm{mAb}$ approved for cancer therapy and is used for the treatment of non-Hodgkin's lymphoma and chronic lymphocytic leukemia (CLL) [173]. HER-2/neutargeting $\mathrm{mAb}$ trastuzumab is approved for the treatment of HER-2/neu-overexpressing breast cancer and metastatic gastric or gastroesophageal junction adenocarcinoma [174]. In mice bearing human lymphoma xenografts, intravenously administered, LNP-formulated mRNA encoding rituximab induced a more pronounced anti-tumor effect compared to the recombinant protein counterpart [175]. Trastuzumab encoded on mRNA intravenously delivered with a liver-targeting LNP formulation and recovered from mouse serum exerted antibody-dependent cellular cytotoxicity (ADCC). The treatment prolonged survival in a HER-2/neu-positive breast cancer xenograft model [176].

Engineered bispecific mAbs, comprising an anti-CD3 $\mathrm{scFv}$ fused to a tumor antigen-specific scFv, are able to redirect $\mathrm{T}$ cells to tumor cells and promote tumor cell killing [177]. The small molecular weight of bispecific mAbs allows efficient penetration of tumor tissue but comes with the drawback of a short serum half-life. mRNA with reduced immunostimulatory activity was investigated for the systemic delivery of bispecific mAbs targeting CD3 and either CLDN6, CLDN18.2 or epithelial cell adhesion molecule (EpCAM) [178]. Polymerlipid-based transfection reagent-formulated, $\mathrm{N}^{1}$-methylpseudouridine-modified and dsRNA-purified bispecific mAb-encoding mRNA (called RiboMAB) was translated in the liver after intravenous administration and resulted in sustained plasma antibody concentration over several days in mice. In contrast, non-nucleotide modified and non-dsRNA purified mRNA induced only minimal plasma concentrations of bispecific mAbs, highlighting the importance of engineering mRNA for enhanced protein production. The favorable pharmacokinetic profile of modified and purified mRNA was associated with the induction of T-cell cytotoxicity and superior anti-tumor activity against human ovarian cancer xenografts as compared to recombinant mAb.

In contrast to systemic exposure mediated through intravenous injection, local mRNA translation by direct injection into a specific tissue or by transfection of specific cell types ex vivo restricts the therapeutic activity of the translated protein to the target cells or their intermediate surroundings. Intratumoral injection of mouse tumors with an antagonistic anti-PD-L1 mAb-encoding self-amplifying (sa)RNA, which is derived from alpha- or flaviviruses and encodes both the protein of interest and a replicase for RNA amplification, resulted in superior anti-tumor efficacy compared to the intraperitoneally or intratumorally administered recombinant protein counterpart. Intratumoral saRNA administration mediated anti-PD-L1 mAb translation in transfected cells and promoted $\mathrm{CD} 8^{+} \mathrm{T}$ cell infiltration into the tumor [179].

Adoptive transfer of DCs transfected ex vivo with mRNA encoding an agonistic anti-GITR mAb delayed tumor growth in mice in the absence of an antigenspecific immunization, with efficacy being comparable to that of intravenous delivery of high amounts $(1 \mathrm{mg})$ of recombinant anti-GITR mAb [180]. The administration of DCs co-transfected with mRNAs encoding an agonistic anti-GITR $m A b$ or a soluble GITRL-Fc fusion protein, antagonistic anti-CTLA- 4 mAb and Trp- 2 mRNA further expanded this approach. The combined transfection of GITRL-Fc, anti-CTLA- $4 \mathrm{mAb}$ and Trp-2 mRNA led to significant prolonged survival of mice compared to either Trp- 2 mRNA or Trp- 2 and anti-CTLA- 4 mAb mRNA or Trp-2 and GITRL-Fc mRNA-transfected DCs [181]. In vitro, these multi-transfected DCs improved the cytotoxicity of CTLs while inhibiting the induction of regulatory $\mathrm{CD}^{+} \mathrm{T}$ cells (Tregs). The concept was subsequently explored in a small trial including two patients with metastatic melanoma (NCT01216436) (Table 3).

To increase bispecific $\mathrm{mAb}$ concentration and persistence in the tumor proximity, $\mathrm{T}$ cells were transfected with mRNA encoding the CD19-targeting bispecific $T$ cell enganger (BiTE) blinatumomab approved for the treatment of certain types of acute lymphoblastic leukemia (ALL). Secretion of the BiTE led to the release of inflammatory cytokines and efficient killing of tumor cells by transfected $\mathrm{T}$ cells in vitro [183]. These observations correlated with enhanced in vivo anti-tumor efficacy upon infusion of mRNA-electroporated $\mathrm{T}$ cells in a mouse model of leukemia.

\section{mRNA-encoded immunomodulators}

mRNA-encoded immunomodulators investigated so far comprise cytokines as well as co-stimulatory ligands and receptors (see Table 3 for those in clinical development).

When using mRNA to produce immunomodulators in vivo, a high protein yield is desirable. The majority of 
Table 3 List of all active, completed or terminated clinical trials of mRNA antibodies and immunomodulators in cancer therapy

\begin{tabular}{|c|c|c|c|c|c|c|}
\hline Sponsor & $\begin{array}{l}\text { Therapy (delivery } \\
\text { route) }\end{array}$ & Indication & $\begin{array}{l}\text { ClinicalTrial.gov } \\
\text { identifier } \\
\text { (phase, } \\
\text { allocation) }\end{array}$ & Combination & Opened & Status \\
\hline \multicolumn{7}{|l|}{ Antibodies } \\
\hline Duke University & $\begin{array}{l}\text { DC with GITRL/anti- } \\
\text { CTLA-4 mAb mRNA } \\
\text { (i.n.) }\end{array}$ & Metastatic melanoma & NCT01216436 (I) & $\begin{array}{l}\text { Melanoma } \\
\text { TAA mRNA } \\
\text { transfected } \\
\text { DCs }\end{array}$ & 2010 & $\begin{array}{l}\text { Terminated } \\
\text { (lack of } \\
\text { personnel) }\end{array}$ \\
\hline \multicolumn{7}{|l|}{ Immunomodulators } \\
\hline \multicolumn{7}{|l|}{ Cytokines } \\
\hline $\begin{array}{l}\text { Medimmune LLC, } \\
\text { Moderna TX Inc. }\end{array}$ & $\begin{array}{l}\text { LNP with IL-12 } \\
\text { mRNA (i.t.) }\end{array}$ & Solid tumors & NCT03946800 (I) & Durvalumab & 2019 & Recruiting \\
\hline $\begin{array}{l}\text { Moderna TX Inc., } \\
\text { AstraZeneca }\end{array}$ & $\begin{array}{l}\text { LNP with OX40L, IL- } \\
23 \text { and IL-36y mRNA } \\
\text { (i.t.) }\end{array}$ & $\begin{array}{l}\text { Relapsed/refractory solid tumor } \\
\text { malignancies or lymphoma, TNBC, HNSCC, } \\
\text { Non-Hodgkin lymphoma, urothelial cancer }\end{array}$ & NCT03739931 (I) & Durvalumab & 2018 & $\begin{array}{l}\text { Recruiting } \\
\text { [182] }\end{array}$ \\
\hline $\begin{array}{l}\text { Sanofi, BioNTech } \\
\text { SE }\end{array}$ & $\begin{array}{l}\text { sclL-12, IL-15sushi, } \\
\text { IFNa and GM-CSF } \\
\text { mRNA (i.t.) }\end{array}$ & Metastatic neoplasms & $\begin{array}{l}\text { NCT03871348 (II, } \\
\text { non-randomized) }\end{array}$ & Cemiplimab & 2019 & Recruiting \\
\hline \multicolumn{7}{|c|}{ Stimulatory ligands and receptors } \\
\hline $\begin{array}{l}\text { eTheRNA } \\
\text { Immunotherapies } \\
\text { Nv. }\end{array}$ & $\begin{array}{l}\text { TriMix (CD70, } \\
\text { CD40L, caTLR4) } \\
\text { mRNA and TAA } \\
\text { mRNA (i.n.) }\end{array}$ & Melanoma & NCT03394937 (I) & None & 2018 & Recruiting \\
\hline Moderna TX Inc. & $\begin{array}{l}\text { LNP-OX40L mRNA } \\
\text { (i.t.) }\end{array}$ & $\begin{array}{l}\text { Relapsed/refractory solid tumor } \\
\text { malignancies or lymphoma, ovarian } \\
\text { cancer }\end{array}$ & $\begin{array}{l}\text { NCT03323398 (I/ } \\
\text { II, non- } \\
\text { randomized) }\end{array}$ & Durvalumab & 2017 & Recruiting \\
\hline $\begin{array}{l}\text { Universitair } \\
\text { Ziekenhuis Brussel, } \\
\text { eTheRNA } \\
\text { Immunotherapies } \\
\text { Nv. }\end{array}$ & $\begin{array}{l}\text { TriMix (CD70, } \\
\text { CD40L, caTLR4) } \\
\text { mRNA (i.t.) }\end{array}$ & Early resectable breast cancer & NCT03788083 (I) & None & 2018 & Recruiting \\
\hline
\end{tabular}

From ClinicalTrial.gov (keywords: cancer AND mRNA AND immunomodulator OR cytokine OR co-stimulator OR antibody) on Dec 1, 2020 and PubMed literature search. ca constitutively active, CD4OL CD40 ligand, CTLA-4 cytotoxic T-lymphocyte-associated protein 4, DC dendritic cell, GITRL glucocorticoid-induced tumor necrosis factor receptor family-related protein ligand, GM-CSF granulocyte-macrophage colony stimulating factor, HNSCC head and neck squamous cell carcinoma, i.n. intranodal, i.t. intratumoral, IFN interferon, IL interleukin, LNP lipid nanoparticle, $m A b$ monoclonal antibody, OX4OL OX40 ligand, sc single-chain, TAA tumorassociated antigen, TLR toll-like receptor, TNBC triple-negative breast cancer

studies that relied on mRNA translation upon intravenous or intratumoral administration used nucleosidemodified mRNA, while approaches involving ex vivo transfected target cells did not attempt to attenuate the inherent immunostimulatory activity of the mRNA.

\section{Cytokines}

Recombinant $\mathrm{T}$ cell-stimulating cytokines are a preclinically validated treatment concept [184-186], the clinical development of which is hampered by substantial toxicity.

IL-2 is a key cytokine involved in differentiation, proliferation, survival and effector function of $\mathrm{T}$ cells and has been approved for the treatment of melanoma and RCC [187]. Major limitations of recombinant IL-2 are its preferential stimulation of Treg expansion and its short serum half-life, demanding high and frequent dosing which in turn potentiates adverse effects. The rationale for using mRNA to express IL-2 in vivo is to prolong the production of the cytokine, reducing peak serum concentration in favor of protracted activity. Two IL-2 encoding investigational nucleoside-modified RNALNP products are in development. One encodes an IL-2 with an extended half-life and is developed in combination with an IL-7 encoding RNA-LNP [188, 189]. In mice, systemic administration of these two cytokine RNA-LNPs synergistically enhanced vaccine-mediated induction of antigen-specific $\mathrm{CD}^{+} \mathrm{T}$ cells and increased the ratio of antigen-specific $\mathrm{CD}^{+} \mathrm{T}$ cells over Tregs, translating into superior control of syngeneic tumors. The second RNA-LNP codes for an engineered IL-2 variant with reduced Treg bias [188, 189]. The IL-2 variant was generated by rational design with the objective of decreasing the binding affinity to the IL-2 receptor (IL-2R) $\alpha$ chain primarily expressed by Tregs, and increasing the binding affinity to the IL-2R $\beta$ chain 
expressed by all $\mathrm{T}$ cells, including effector $\mathrm{T}$ cells. In syngeneic tumor-bearing mice, intravenous administration of the IL-2 variant RNA-LNP expanded spontaneous anti-tumor $\mathrm{T}$-cell responses without significant elevation of Tregs, leading to a strong increase of the $\mathrm{CD}^{+} \mathrm{T}$ cell to Treg ratio. The IL- 2 variant RNA-LNP proved effective in syngeneic mouse tumor models, and the anti-tumor effect was significantly enhanced in combination with RNA-LPX vaccination or PD-1/PD-L1 checkpoint inhibition.

IL-15 is functionally related to IL-2, as both signal via IL-2R $\beta$ and the common $\gamma$ chain (IL-2R $\beta \gamma$ ), and thereby stimulate T cells and NK cells [190]. Whereas IL-2 is crucial for the development and homeostasis of Tregs and supports AICD to control auto-reactive $\mathrm{T}$ cells, IL-15 prolongs the survival of $\mathrm{CD} 8^{+}$memory $\mathrm{T}$ cells [191]. IL-15 has a short serum half-life and cancer patients that received intravenous infusion of recombinant IL-15 experienced dose-limiting toxicity [192]. Signaling is induced when IL-15 presented on membrane-associated IL-15R $\alpha$ binds IL-2R $\beta \gamma$ receptor complexes on $\mathrm{T}$ cells in trans. To avoid systemic exposure to $\mathrm{IL}-15, \mathrm{CD}^{+} \mathrm{T}$ cells were transfected ex vivo with mRNA encoding an IL-15-IL-15R $\alpha$ fusion construct (IL-15sushi). Autonomous stimulation of the trimeric IL-15R in cis enhanced the cytotoxicity of the $\mathrm{T}$ cells in vitro and when administered to mice, these cells proliferated better [193].

IL-12 is a potent mediator of $T_{H} 1$ immunity and exerts significant anti-tumor activity in mouse tumor models. In humans, IL-12 is associated with potentially lethal toxicity upon systemic administration [194, 195]. One study investigated $\mathrm{T}$ cells transfected with mRNA encoding a single-chain IL-12 (scIL-12) consisting of the p35 and p40 subunits. Intratumoral injection of scIL-12expressing $\mathrm{T}$ cells resulted in complete rejection of both injected and distant tumor lesions in syngeneic and xenograft mouse models. Co-electroporation of $\mathrm{T}$ cells with 4-1BBL mRNA further increased anti-tumor efficacy [196]. Local expression of IL-12 was also achieved through intratumoral delivery of LNPs containing scIL$12 \mathrm{~N}^{1}$-methylpseudouridine-modified mRNA. In mouse tumor models, a single intratumoral injection promoted tumor regression, which required IFNy and $\mathrm{CD}^{+} \mathrm{T}$ cells [197]. In a corresponding phase I clinical trial, the human scIL-12 MEDI1191 is being evaluated in patients with solid tumors (NCT03946800). In a different approach, $\quad \mathrm{N}^{1}$-methylpseudouridine-modified scIL-12 RNA-LNPs administered intravenously to mice bearing hepatocellular carcinomas reduced liver tumor burden and prolonged survival, without apparent liver toxicity [198]. Reporter mRNA-containing LNPs demonstrated that the translated protein was confined to the tumors and non-malignant regions of the liver and the spleen.
Various mRNAs can be easily mixed and formulated together as a single drug product, a technological property that has encouraged the development of combinatorial approaches. Intratumoral administration of LNPformulated $\mathrm{N}^{1}$-methylpseudouridine-modified mRNAs encoding IL-36y (a pro-inflammatory cytokine acting as alarmin), IL-23 (a regulator of inflammation) and OX40L demonstrated regression of established tumors in three syngeneic tumor models [199]. Inflammatory cytokines and chemokines in the tumor microenvironment (TME) and recruitment and activation of multiple $\mathrm{DC}$ and $\mathrm{T}$ cell types increased upon triplet mRNA treatment. These cytokine responses were reproduced in human cell culture studies. A phase I dose escalation study is evaluating the mixture alone or in combination with durvalumab in 126 patients with relapsed/refractory solid tumors or lymphoma (NCT03739931) [182]. Dose expansion cohorts contain patients with TNBC, HNSCC, non-Hodgkin lymphoma, and urothelial cancer. In addition, a mix of scIL-12, IL-15sushi, GM-CSF and IFN $\alpha$ mRNA alone or in combination with cemiplimab is being tested in a phase I clinical trial in 231 patients with metastatic neoplasms (NCT03871348) [200].

In a combination approach using a single mRNA construct, IFN $\beta$ was fused with the ectodomain of the transforming growth factor (TGF) $\beta$ receptor II to stimulate innate immunity while antagonizing the suppressive function of TGF $\beta$ [201]. In vitro, the fusion construct increased surface expression of MHC class I and PD-L1 by tumor cells, improved T-cell priming by DCs, and diminished the suppressive capacity of myeloid-derived suppressor cells. This pharmacological profile resulted in tumor growth delay in syngeneic tumor models.

\section{Stimulatory ligands and receptors}

Interactions of stimulatory ligands and receptors provide inflammatory signals to the immune system that can be exploited for cancer immunotherapy. mRNA can be used to transiently equip cells with stimulatory receptors, enabling transient activation of strong inflammatory signals.

Modification of intracellular receptor domains to generate ca receptors is helpful to provide cells with autonomous stimuli. The transfection of $\mathrm{T}$ cells, isolated either from PBLs or tumor-infiltrating lymphocytes (TILs), with caTLR4 mRNA, caCD40 mRNA, or both, enhanced the production of IFN $\gamma$ and TNF $\alpha$, upregulated 4-1BB and $\mathrm{CD} 25$, and increased the cytolytic activity against autologous melanoma cells in vitro [202, 203]. Building on this strategy, the authors of these studies added cytokine mRNAs coding for membrane-anchored variants of IL-2, scIL-12 and IL-15. The membrane-associated cytokines bound their corresponding surface receptors mainly in cis. Co-transfection of cytokine mRNAs with 
caTLR4 mRNA, caCD40 mRNA, or both, enhanced IFN $\gamma$ production by $\mathrm{T}$ cells, induced upregulation of $\mathrm{T}$ cell activation molecules (CD25, 4-1BB, OX40), and improved the cytotoxicity of TILs against autologous melanoma cells in vitro in comparison to cells transfected with caTLR4 mRNA, caCD40 mRNA, or both [204, 205].

The transient nature of mRNA translation is appealing for the direct in vivo delivery of stimulatory ligand and receptor-coding mRNA. The injection of naked TriMix mRNA (caTLR4 and co-stimulatory ligands CD70 and CD40L; as described above) directly into the tumor resulted in systemic therapeutic anti-tumor activity in various mouse models and led to a phase I clinical trial in patients with early, resectable breast cancer lesions (NCT03788083) [206]. In addition, LNP-formulated OX40L mRNA entered clinical phase I development in patients with relapsed/refractory solid tumors, lymphoma and ovarian cancer, alone or in combination with durvalumab (NCT03323398). So far, OX40L monotherapy proved to be safe while exerting pro-inflammatory activity in the injected tumor lesions [207].

Resorting to the combination of co-stimulatory ligands and receptors (CD70, OX40L, CD80, CD86), as well as cytokines (IL-12, IFN $\gamma$ ), different mixtures of formulated $5{ }^{\prime}$-methylcytidine- and pseudouridine-modified mRNAs were injected directly into mouse tumors. Among all tested combinations, the triplet of OX40L, CD80 and CD86 mRNA induced the strongest anti-tumor immunity in subcutaneous A20 and CT26 tumor-bearing mice [208].

\section{Conclusion}

The development and worldwide approval or authorization of mRNA vaccines against SARS-CoV-2 within less than 1 year upon occurrence of the COVID19 pandemic showcased the enormous potential of mRNA technology. COVID-19 mRNA vaccines were rapidly developed, have a favorable safety profile, and outperform established technologies with efficacies around 95\% of preventing COVID-19 [24, 114].

This rapid response to the pandemic leveraged the rich source of scientific, clinical, manufacturing and regulatory lessons learned over decades of exploring mRNA technology for the design and clinical development of therapeutic cancer vaccines. In turn, the insights gained in the process of advancing mRNA for the first time through all stages of pharmaceutical drug development to a commercial product will now feed back into its application for cancer immunotherapy.

The beauty of mRNA technology is the broad bandwidth of its versatility. By modifying building blocks, structural elements, and formulations of the synthetic mRNA, a variety of features including targeting to defined cells, duration of expression, and immunological effects can be adapted. This expands the design space for mRNA beyond therapeutic cancer vaccination. mRNA is now utilized for the most diverse immunotherapeutic approaches, including the equipping of immune cells with antigen receptors and the in vivo production of therapeutic proteins such as antibodies or immunomodulators. mRNA CAR-T cells have the potential to improve the safety profile of CAR-T cell therapy and allow concurrent modification of the lymphocytes by codelivery of additional mRNAs. mRNA-based immunomodulators successfully entered clinical testing. Intratumoral injection of mRNA-encoded cytokines and costimulatory ligands demonstrated feasibility and induction of anti-tumor immune responses.

mRNA is expected to become one of the major pillars of drug development. With an increasing number of concepts entering clinical trials, the first approval of an mRNA therapeutic against cancer is nearing.

\section{Abbreviations}

ACT: Adoptive cell transfer; ADCC: Antibody-dependent cellular cytotoxicity; AICD: Activation-induced cell death; ALL: Acute lymphoblastic leukemia;

AML: Acute myeloid leukemia; APC: Antigen-presenting cell; AUC: Area under the curve; BCMA: B-cell maturation antigen; BiTE: Bispecific T cell engager; BMCA: B cell maturation antigen; ca: Constitutively active; CAR: Chimeric antigen receptor; CD40L: CD40 ligand; CEA: Carcinoembryonic antigen; CLDN6: Claudin 6; CLEC9A: Mannose receptors and C-type lectin domain family 9; CLL: Chronic lymphocytic leukemia; c-Met: Protein kinase Met; CTLA-4: Cytotoxic T-lymphocyte-associated protein 4; DC: Dendritic cell; DcR3: Decoy receptor 3; ds: Double-stranded; EpCAM: Epithelial cell adhesion molecule; ELISpot: Enzyme-linked immune absorbent spot;

GITR: Glucocorticoid-induced tumor necrosis factor receptor;

GITRL: Glucocorticoid-induced tumor necrosis factor receptor ligand; GM-CSF: Granulocyte-macrophage colony-stimulating factor; HCMV: Human cytomegalovirus; HER-2: Human epidermal growth factor receptor 2;

HLA: Human leukocyte antigen; HNSCC: Head and neck squamous cell carcinoma; HPV: Human papilloma virus; hTERT: Human telomerase reverse transcriptase; Ig: Immunoglobulin; i.d.: Intradermal; i.n.: Intranodal;

i.t.: Intratumoral; i.v.: Intravenous; ICOSL: Inducible T cell co-stimulatory ligand; IFN: Interferon; IKKb: Inhibitor of nuclear factor kappa-B kinase subunit beta; IL: Interleukin; IL-2R: IL-2 receptor; iNeST: Individualized neoantigen-specific immunotherapy; ISG: IFN-stimulated gene; IVT: In vitro transcription; LAMP: Lysosome-associated membrane protein; MHC: Major

histocompatibility complex; LNP: Lipid nanoparticle; mAb: Monoclonal antibody; MAGE: Melanoma-associated antigen; MART: Melanoma antigen recognized by T cells; MDA5: Melanoma differentiation-associated protein 5; mRCC: Metastatic renal cell carcinoma; mRNA: Messenger RNA; MUC1: Mucin 1; neoAg: Neoantigen; NK: Natural killer; NKG2D: Natural killer group 2D; NSCLC: Non-small-cell lung cancer; NY-ESO-1: New York esophageal squamous cell carcinoma-1; OAS: 2',5'-oligoadenylate synthetase;

OX40L: OX40 ligand; PAP: Prostatic acid phosphatase; PD-1: Programmed cell death protein 1; PDAC: Pancreatic ductal adenocarcinoma; PEG: Polyethylene glycol; PGE2: Prostaglandin E2; PKR: IFN-inducible double-stranded RNAactivated protein kinase; PD-L1: Programmed cell death ligand 1;

PRAME: Melanoma antigen preferentially expressed in tumors; PRR: Pattern recognition receptors; PSA: Prostate-specific antigen; PSCA: Prostate stem cell antigen; PSMA: Prostate-specific membrane antigen; RCC: Renal cell carcinoma; RIG-I: Retinoic acid-inducible gene 1; RNA-LPX: Liposomeformulated mRNA; sa: Self-amplifying; sc: Single chain; scFv: Single-chain variable fragment; ss: Single-stranded; STEAP: 6-transmembrane epithelial antigen of prostate; STING: Stimulator of interferon gene; TAA: Tumorassociated antigen; TCR: T cell receptor; td: Tetanus-diphtheria toxoid; TGF: Transforming growth factor; TIL: Tumor-infiltrating lymphocytes; TLR: Toll-like receptor; TME: Tumor microenvironment; TNBC: Triple-negative 
breast cancer; TNF: Tumor necrosis factor; TPBG: Trophoblast glycoprotein; TPTE: Transmembrane phosphatase with tensin homology; Treg: Regulatory $\mathrm{CD}^{+}{ }^{+}$T cell; TriMix: CD40L, CD70 and constitutively active TLR4 mRNA; Trp2: Tyrosinase-related protein-2; TSA: Tumor-specific antigen; UTR: Untranslated region; WT1: WILMS' tumor 1; 4-1BBL: 4-1BB ligand

\section{Acknowledgements}

We thank Andrew Finlayson (BioNTech SE) for thorough proof-reading and helpful discussions.

\section{Authors' contributions}

$J D B, D R, N S, M V$ and LMK designed, and JDB, DR and NS wrote the manuscript. US, ÖT, MV and LMK reviewed, edited and approved the final version of the manuscript. The authors read and approved the final manuscript.

\section{Funding}

Not applicable.

\section{Availability of data and materials}

Not applicable.

\section{Declarations}

Ethics approval and consent to participate

Not applicable.

\section{Consent for publication}

Not applicable.

\section{Competing interests}

NS, US, ÖT, MV and LMK are authors of studies mentioned in this review. JDB, MV and LMK are employees and US and ÖT are cofounders and management board members of BioNTech SE (Mainz, Germany). JDB, US, ÖT, MV and LMK hold securities from BioNTech SE. All other authors declare that they have no competing interests.

\section{Author details}

${ }^{1}$ BioNTech SE, An der Goldgrube 12, 55131 Mainz, Germany. ${ }^{2}$ TRON Translational Oncology at the University Medical Center of the Johannes Gutenberg-University gGmbH, Freiligrathstraße 12, 55131 Mainz, Germany.

\section{Received: 18 January 2021 Accepted: 15 March 2021}

\section{Published online: 15 April 2021}

\section{References}

1. Kuhn AN, Diken M, Kreiter S, Selmi A, Kowalska J, JEMIELITY J, et al. Phosphorothioate cap analogs increase stability and translational efficiency of RNA vaccines in immature dendritic cells and induce superior immune responses in vivo. Gene Ther. 2010;17(8):961-71. https://doi.org/10.1038/gt.2 010.52

2. Strenkowska M, Grzela R, Majewski M, Wnek K, Kowalska J, Lukaszewicz M, Zuberek J, Darzynkiewicz E, Kuhn AN, Sahin U, Jemielity J. Cap analogs modified with 1,2-dithiodiphosphate moiety protect mRNA from decapping and enhance its translational potential. Nucleic Acids Res. 2016;44(20):957890. https://doi.org/10.1093/nar/gkw896

3. Rehwinkel J, Tan CP, Goubau D, Schulz O, Pichlmair A, Bier K, et al. RIG-I detects viral genomic RNA during negative-strand RNA virus infection. Cell. 2010;140(3):397-408. https://doi.org/10.1016/j.cell.2010.01.020.

4. Nallagatla SR, Toroney R, Bevilacqua PC. A brilliant disguise for self RNA: 5'end and internal modifications of primary transcripts suppress elements of innate immunity. RNA Biol. 2008;5(3):140-4. https://doi.org/10.4161/rna.5.3. 6839

5. Holtkamp S, Kreiter S, Selmi A, Simon P, Koslowski M, Huber C, Türeci Ö, Sahin U. Modification of antigen-encoding RNA increases stability, translational efficacy, and T-cell stimulatory capacity of dendritic cells. Blood. 2006;108(13):4009-17. https://doi.org/10.1182/blood-2006-04-015024 .

6. Kuhn AN, Beißert T, Simon P, Vallazza B, Buck J, Davies BP, et al. mRNA as a versatile tool for exogenous protein expression. Curr Gene Ther. 2012;12(5): 347-61. https://doi.org/10.2174/156652312802762536 .
7. Sample PJ, Wang B, Reid DW, Presnyak V, McFadyen IJ, Morris DR, et al. Human 5' UTR design and variant effect prediction from a massively parallel translation assay. Nat Biotechnol. 2019;37(7):803-9. https://doi.org/10.1038/ s41587-019-0164-5

8. Jia L, Mao Y, Ji Q, Dersh D, Yewdell JW, Qian S-B. Decoding mRNA translatability and stability from the 5' UTR. Nat Struct Mol Biol. 2020;27(9): 814-21. https://doi.org/10.1038/s41594-020-0465-x .

9. Chen C-YA, Shyu A-B. AU-rich elements: characterization and importance in mRNA degradation. Trends Biochem Sci. 1995;20(11):465-70. https://doi. org/10.1016/50968-0004(00)89102-1 .

10. Bernstein P, Peltz SW, Ross J. The poly(a)-poly(a)-binding protein complex is a major determinant of mRNA stability in vitro. Mol Cell Biol. 1989;9(2):65970. https://doi.org/10.1128/MCB.9.2.659

11. Mockey M, Gonçalves C, Dupuy FP, Lemoine FM, Pichon C, Midoux P. mRNA transfection of dendritic cells: synergistic effect of ARCA mRNA capping with poly(a) chains in cis and in trans for a high protein expression level. Biochem Biophys Res Commun. 2006;340(4):1062-8. https://doi.org/1 0.1016/j.bbrc.2005.12.105 .

12. Cannarozzi G, Schraudolph NN, Faty M, von Rohr P, Friberg MT, Roth AC, Gonnet P, Gonnet G, Barral Y. A role for codon order in translation dynamics. Cell. 2010;141 (2):355-67. https://doi.org/10.1016/j.cell.2010.02.036

13. Pastor F, Berraondo P, Etxeberria I, Frederick J, Sahin U, Gillboa E, Melero I. An RNA toolbox for cancer immunotherapy. Nat Rev Drug Discov. 2018; 17(10):751-67. https://doi.org/10.1038/nrd.2018.132.

14. Kroczynska B, Mehrotra S, Arslan AD, Kaur S, Platanias LC. Regulation of interferon-dependent mRNA translation of target genes. J Interf Cytokine Res. 2014;34(4):289-96. https://doi.org/10.1089/jir.2013.0148 .

15. Munir $M, B e r g ~ M$. The multiple faces of proteinkinase $R$ in antiviral defense. Virulence. 2013;4(1):85-9. https://doi.org/10.4161/viru.23134 .

16. Karikó K, Buckstein $\mathrm{M}, \mathrm{Ni}$ H, Weissman D. Suppression of RNA recognition by toll-like receptors: the impact of nucleoside modification and the evolutionary origin of RNA. Immunity. 2005;23(2):165-75. https://doi.org/10.1 016/j.immuni.2005.06.008

17. Karikó K, Muramatsu H, Welsh FA, Ludwig J, Kato H, Akira S, Weissman D. Incorporation of Pseudouridine into mRNA yields superior nonimmunogenic vector with increased translational capacity and biological stability. Mol Ther. 2008;16(11):1833-40. https://doi.org/10.1038/ mt.2008.200

18. Karikó K, Muramatsu H, Keller JM, Weissman D. Increased erythropoiesis in mice injected with submicrogram quantities of Pseudouridine-containing mRNA encoding erythropoietin. Mol Ther. 2012;20(5):948-53. https://doi. org/10.1038/mt.2012.7.

19. Andries O, Mc Cafferty S, de Smedt SC, Weiss R, Sanders NN, Kitada T. N(1)methylpseudouridine-incorporated mRNA outperforms pseudouridineincorporated mRNA by providing enhanced protein expression and reduced immunogenicity in mammalian cell lines and mice. J Control Release. 2015;217:337-44. https://doi.org/10.1016/j.jconrel.2015.08.051

20. Baiersdörfer M, Boros G, Muramatsu H, Mahiny A, Vlatkovic I, Sahin U, Karikó K. A facile method for the removal of dsRNA contaminant from in vitrotranscribed mRNA. Mol Ther Nucleic Acids. 2019;15:26-35. https://doi.org/1 0.1016/.omtn.2019.02.018

21. Karikó K, Muramatsu H, Ludwig J, Weissman D. Generating the optimal mRNA for therapy: HPLC purification eliminates immune activation and improves translation of nucleoside-modified, protein-encoding mRNA. Nucleic Acids Res. 2011;39(21):e142. https://doi.org/10.1093/nar/gkr695.

22. Walsh EE, Frenck RW, Falsey AR, Kitchin N, Absalon J, Gurtman A, et al. Safety and immunogenicity of two RNA-based Covid-19 vaccine candidates. N Engl J Med. 2020;383(25):2439-50. https://doi.org/10.1056/NEJMoa202 7906 .

23. Anderson EJ, Rouphael NG, Widge AT, Jackson LA, Roberts PC, Makhene M, Chappell JD, Denison MR, Stevens LJ, Pruijssers AJ, McDermott A, Flach B, Lin BC, Doria-Rose NA, O'Dell S, Schmidt SD, Corbett KS, Swanson PA 2nd, Padilla M, Neuzil KM, Bennett H, Leav B, Makowski M, Albert J, Cross K, Edara W, Floyd K, Suthar MS, Martinez DR, Baric R, Buchanan W, Luke CJ, Phadke VK, Rostad CA, Ledgerwood JE, Graham BS, Beigel JH, mRNA-1273 Study Group. Safety and immunogenicity of SARS-CoV-2 mRNA-1273 vaccine in older adults. N Engl J Med. 2020;383(25):2427-38. https://doi.org/10.1056/ NEJMoa2028436

24. Polack FP, Thomas SJ, Kitchin N, Absalon J, Gurtman A, Lockhart S, Perez JL, Pérez Marc G, Moreira ED, Zerbini C, Bailey R, Swanson KA, Roychoudhury S, Koury K, Li P, Kalina WW, Cooper D, Frenck RW Jr, Hammitt LL, Türeci Ö, Nell 
H, Schaefer A, Ünal S, Tresnan DB, Mather S, Dormitzer PR, Şahin U, Jansen KU, Gruber WC, C4591001 Clinical Trial Group. Safety and efficacy of the BNT162b2 mRNA Covid-19 vaccine. N Engl J Med. 2020;383(27):2603-15. https://doi.org/10.1056/NEJMoa2034577.

25. Conry RM, et al. Characterization of a messenger RNA polynucleotide vaccine vector. Cancer Res. 1995;55:1397-400 Cancer Res 1995; 55:1397.

26. Boczkowski D, Nair SK, Snyder D, Gilboa E. Dendritic cells pulsed with RNA are potent antigen-presenting cells in vitro and in vivo. J Exp Med. 1996; 184(2):465-72. https://doi.org/10.1084/jem.184.2.465

27. Anguille $\mathrm{S}$, van de Velde AL, Smits EL, van Tendeloo VF, Juliusson G, Cools N, Nijs G, Stein B, Lion E, van Driessche A, Vandenbosch I, Verlinden A, Gadisseur AP, Schroyens WA, Muylle L, Vermeulen K, Maes MB, Deiteren K, Malfait R, Gostick E, Lammens M, Couttenye MM, Jorens P, Goossens H, Price DA, Ladell K, Oka Y, Fujiki F, Oji Y, Sugiyama H, Berneman ZN. Dendritic cell vaccination as postremission treatment to prevent or delay relapse in acute myeloid leukemia. Blood. 2017;130(15):1713-21. https://doi. org/10.1182/blood-2017-04-780155

28. Amin A, Dudek AZ, Logan TF, Lance RS, Holzbeierlein JM, Knox JJ, Master VA, Pal SK, Miller WH, Karsh LI, Tcherepanova IY, DeBenedette MA, Williams WL, Plessinger DC, Nicolette CA, Figlin RA. Survival with AGS-003, an autologous dendritic cell-based immunotherapy, in combination with sunitinib in unfavorable risk patients with advanced renal cell carcinoma (RCC): phase 2 study results. J Immunother Cancer. 2015;3(1):14. https://doi. org/10.1186/s40425-015-0055-3

29. Figlin RA, Tannir NM, Uzzo RG, Tykodi SS, Chen DYT, Master V, Kapoor A, Vaena D, Lowrance W, Bratslavsky G, DeBenedette M, Gamble A, Plachco A, Norris MS, Horvatinovich J, Tcherepanova IY, Nicolette CA, Wood CG, ADAPT study group. Results of the ADAPT phase 3 study of Rocapuldencel-T in combination with Sunitinib as first-line therapy in patients with metastatic renal cell carcinoma. Clin Cancer Res. 2020;26(10):2327-36. https://doi.org/1 0.1158/1078-0432.CCR-19-2427

30. Figlin R, Nicolette C, Tannir N, Tykodi SS, Chen D, Master V, Lane B, Debenedette M, Monesmith T, Tan W, Leland S, Wood CG. Interim analysis of the phase 3 ADAPT trial evaluating rocapuldencel-T (AGS-003), an individualized immunotherapy for the treatment of newly-diagnosed patients with metastatic renal cell carcinoma (mRCC). Ann Oncol. 2017;28: v404. https://doi.org/10.1093/annonc/md×376.003

31. Khoury HJ, Collins RH, Blum W, Stiff PS, Elias L, Lebkowski JS, et al. Immune responses and long-term disease recurrence status after telomerase-based dendritic cell immunotherapy in patients with acute myeloid leukemia. Cancer. 2017:123(16):3061-72. https://doi.org/10.1002/cncr.30696

32. Mitchell DA, Batich KA, Gunn MD, Huang M-N, Sanchez-Perez L, Nair SK, Congdon KL, Reap EA, Archer GE, Desjardins A, Friedman AH, Friedman HS, Herndon II JE, Coan A, McLendon RE, Reardon DA, Vredenburgh JJ, Bigner DD, Sampson JH. Tetanus toxoid and CCL3 improve dendritic cell vaccines in mice and glioblastoma patients. Nature. 2015;519(7543):366-9. https://doi. org/10.1038/nature14320.

33. Batich KA, Mitchell DA, Healy P, Herndon JE, Sampson JH. Once, twice, three times a finding: reproducibility of dendritic cell vaccine trials targeting Cytomegalovirus in Glioblastoma. Clin Cancer Res. 2020;26(20):5297-303. https://doi.org/10.1158/1078-0432.CCR-20-1082 .

34. Kongsted P, Borch TH, Ellebaek E, Iversen TZ, Andersen R, Met Ö, et al. Dendritic cell vaccination in combination with docetaxel for patients with metastatic castration-resistant prostate cancer: a randomized phase II study. Cytotherapy. 2017;19(4):5-513. https://doi.org/10.1016/j.jcyt.2017.01.007.

35. Boudewijns S, Bloemendal M, de Haas N, Westdorp H, Bol KF, Schreibelt G, Aarntzen EHJG, Lesterhuis WJ, Gorris MAJ, Croockewit A, van der Woude LL, van Rossum MM, Welzen M, de Goede A, Hato SV, van der Graaf WTA, Punt CJA, Koornstra RHT, Gerritsen WR, Figdor CG, de Vries IJM. Autologous monocyte-derived DC vaccination combined with cisplatin in stage III and IV melanoma patients: a prospective, randomized phase 2 trial. Cancer Immuno Immunother. 2020;69(3):477-88. https://doi.org/10.1007/s00262-019-02466-x .

36. Gururangan S, Elias Sayour E, Mitchell DA. Total tumor RNA pulsed dendritic cells plus adoptive transfer of ex-vivo enriched autologous T-lymphocytes in the treatment of children with primary brain tumors. NN. 2018;5(10):45. https://doi.org/10.20517/2347-8659.2018.44

37. Wilgenhof S, Corthals J, Heirman C, van Baren N, Lucas S, Kvistborg P, Thielemans K, Neyns B. Phase II study of autologous monocyte-derived mRNA Electroporated dendritic cells (TriMixDC-MEL) plus Ipilimumab in patients with Pretreated advanced melanoma. J Clin Oncol. 2016;34(12): 1330-8. https://doi.org/10.1200/JCO.2015.63.4121.
38. de Keersmaecker B, Claerhout S, Carrasco J, Bar I, Corthals J, Wilgenhof S, et al. TriMix and tumor antigen mRNA electroporated dendritic cell vaccination plus ipilimumab: link between T-cell activation and clinical responses in advanced melanoma. J Immunother Cancer. 2020;8(1):e000329. https://doi.org/10.1136/jitc-2019-000329.

39. Wilgenhof S, Corthals J, Heirman C, Neyns B, Thielemans K. Clinical trials with MRNA electroporated dendritic cells for stage III/IV melanoma patients. J Immunother Cancer. 2015;3(Suppl 2):P211. https://doi.org/10.1186/2 051-1426-3-S2-P211

40. Kranz LM, Diken M, Haas H, Kreiter S, Loquai C, Reuter KC, Meng M, Fritz D, Vascotto F, Hefesha H, Grunwitz C, Vormehr M, Hüsemann Y, Selmi A, Kuhn AN, Buck J, Derhovanessian E, Rae R, Attig S, Diekmann J, Jabulowsky RA, Heesch S, Hassel J, Langguth P, Grabbe S, Huber C, Türeci Ö, Sahin U. Systemic RNA delivery to dendritic cells exploits antiviral defence for cancer immunotherapy. Nature. 2016;534(7607):396-401. https://doi.org/10.1038/na ture18300.

41. Sahin U, Oehm P, Derhovanessian E, Jabulowsky RA, Vormehr M, Gold M, Maurus D, Schwarck-Kokarakis D, Kuhn AN, Omokoko T, Kranz LM, Diken M, Kreiter S, Haas H, Attig S, Rae R, Cuk K, Kemmer-Brück A, Breitkreuz A, Tolliver C, Caspar J, Quinkhardt J, Hebich L, Stein M, Hohberger A, Vogler I, Liebig I, Renken S, Sikorski J, Leierer M, Müller V, Mitzel-Rink H, Miederer M, Huber C, Grabbe S, Utikal J, Pinter A, Kaufmann R, Hassel JC, Loquai C, Türeci Ö. An RNA vaccine drives immunity in checkpoint-inhibitor-treated melanoma. Nature. 2020;585(7823):107-12. https://doi.org/10.1038/s41586020-2537-9

42. Koch SD, Hong $H$, Feyerabend $S$, Retz $M$, Kuebler $H$, Heidenreich A, van Erps T, Schroeder A, Scheel B, Reus V, Kallen KJ, Fotin-Mleczek M, Gnad-Vogt U, Stenzl A. A randomized, double-blind, placebo-controlled, phase I/II trial of RNActive ${ }^{-}$-vaccine $\mathrm{cv} 9104$ in patients with metastatic castrate-refractory prostate cancer (mcrpc): first results of the phase I part. J Immunother Cancer. 2014;2(Suppl 3):P85. https://doi.org/10.1186/2051-1426-2-S3-P85

43. Stenzl A, Feyerabend S, Syndikus I, Sarosiek T, Kübler H, Heidenreich A, Cathomas R, Grüllich C, Loriot Y, Perez Gracia SL, Gillessen S, Klinkhardt U, Schröder A, Schönborn-Kellenberger O, Reus V, Koch SD, Hong HS, Seibel T, Fizazi K, Gnad-Vogt U. Results of the randomized, placebo-controlled phase I/IIB trial of CV9104, an mRNA based cancer immunotherapy, in patients with metastatic castration-resistant prostate cancer (mCRPC). Ann Oncol. 2017;28:v408-9. https://doi.org/10.1093/annonc/md×376.014

44. Kübler H, Scheel B, Gnad-Vogt U, Miller K, Schultze-Seemann W, Vom Dorp $F$, et al. Self-adjuvanted mRNA vaccination in advanced prostate cancer patients: a first-in-man phase I/lla study. J Immunother Cancer. 2015;3(1):26. https://doi.org/10.1186/s40425-015-0068-y .

45. Arance Fernandez AMA, Baurain J-F, Vulsteke C, Rutten A, Soria A, Carrasco $J$, et al. A phase I study (E011-MEL) of a TriMix-based mRNA immunotherapy (ECI-006) in resected melanoma patients: Analysis of safety and immunogenicity. JCO. 2019;37(15_suppl):2641.

46. Howard A. Burris. A phase 1 multicenter study to assess the safety, tolerability and immunogenicity of mRNA-4157 alone in patients with resected solid tumors and in combination with pembrolizumab in patients with unresectable solid tumors. Available from: URL: https://www. businesswire.com/news/home/20190601005011/en/Moderna\%C2\%AOA nnounces-Presentation-of-Interim-Data-from-Phase-1-Study-of-mRNAPersonalized-Cancer-Vaccine-at-2019-ASCO-Annual-Meeting.

47. Perez $C R$, de Palma M. Engineering dendritic cell vaccines to improve cancer immunotherapy. Nat Commun. 2019;10(1):5408. https://doi.org/10.1 038/s41467-019-13368-y

48. Su Z, Dannull J, Heiser A, Yancey D, Pruitt S, Madden J, Coleman D, Niedzwiecki D, Gilboa E, Vieweg J. Immunological and clinical responses in metastatic renal cancer patients vaccinated with tumor RNA-transfected dendritic cells. Cancer Res. 2003:63(9):2127-33.

49. Caruso DA, Orme LM, Neale A, Radcliff FJ, Amor GM, Maixner W, et al. Results of a phase 1 study utilizing monocyte-derived dendritic cells pulsed with tumor RNA in children and young adults with brain cancer. Neuro Oncol. 2004;6(3):236-46. https://doi.org/10.1215/S1152851703000668.

50. Caruso DA, Orme LM, Amor GM, Neale A, Radcliff FJ, Downie P, et al. Results of a Phase I study utilizing monocyte-derived dendritic cells pulsed with tumor RNA in children with Stage 4 neuroblastoma. Cancer. 2005;103(6): 1280-91. https://doi.org/10.1002/cncr.20911.

51. Kyte JA, Mu L, Aamdal S, Kvalheim G, Dueland S, Hauser M, Gullestad HP, Ryder T, Lislerud K, Hammerstad H, Gaudernack G. Phase I/II trial of melanoma therapy with dendritic cells transfected with autologous tumor- 
mRNA. Cancer Gene Ther. 2006;13(10):905-18. https://doi.org/10.1038/sj.cgt. 7700961

52. Mu LJ, Kyte JA, Kvalheim G, Aamdal S, Dueland S, Hauser M, Hammerstad H, Waehre H, Raabe N, Gaudernack G. Immunotherapy with allotumour mRNAtransfected dendritic cells in androgen-resistant prostate cancer patients. Br J Cancer. 2005;93(7):749-56. https://doi.org/10.1038/sj.bjc.6602761

53. Kyte JA, Aamdal S, Dueland S, Sæbøe-Larsen S, Inderberg EM, Madsbu UE, Skovlund E, Gaudernack G, Kvalheim G. Immune response and long-term clinical outcome in advanced melanoma patients vaccinated with tumormRNA-transfected dendritic cells. Oncolmmunology. 2016;5(11):e1232237. https://doi.org/10.1080/2162402X.2016.1232237.

54. Javorovic M, Pohla H, Frankenberger B, Wölfel T, Schendel DJ. RNA transfer by electroporation into mature dendritic cells leading to reactivation of effector-memory cytotoxic T lymphocytes: a quantitative analysis. Mol Ther. 2005;12(4):734-43. https://doi.org/10.1016/j.ymthe.2005.03.034 .

55. Heiser A, Coleman D, Dannull J, Yancey D, Maurice MA, Lallas CD, Dahm P, Niedzwiecki D, Gilboa E, Vieweg J. Autologous dendritic cells transfected with prostate-specific antigen RNA stimulate CTL responses against metastatic prostate tumors. J Clin Investig. 2002;109(3):409-17. https://doi. org/10.1172/JCI0214364

56. Morse MA, Nair SK, Mosca PJ, Hobeika AC, Clay TM, Deng Y, et al. Immunotherapy with autologous, human dendritic cells transfected with Carcinoembryonic antigen mRNA. Cancer Investig. 2003;21(3):341-9. https:// doi.org/10.1081/CNV-120018224

57. Lesterhuis WJ, de Vries IJM, Schreibelt G, Schuurhuis DH, Aarntzen EH, de Boer A, Scharenborg NM, van de Rakt M, Hesselink EJ, Figdor CG, Adema GJ, Punt CJ. Immunogenicity of dendritic cells pulsed with CEA peptide or transfected with CEA mRNA for vaccination of colorectal cancer patients. Anticancer Res. 2010;30(12):5091-7.

58. Aarntzen EHJG, Schreibelt G, Bol K, Lesterhuis WJ, Croockewit AJ, de Wilt $J H W$, et al. Vaccination with mRNA-Electroporated dendritic cells induces robust tumor antigen-specific CD4+ and CD8+ T cells responses in stage III and IV melanoma patients. Clin Cancer Res. 2012;18(19):5460-70. https://doi. org/10.1158/1078-0432.CCR-11-3368

59. Bol KF, Mensink HW, Aarntzen EHJG, Schreibelt G, Keunen JEE, Coulie PG, de Klein A, Punt CJA, Paridaens D, Figdor CG, de Vries IJM. Long overall survival after dendritic cell vaccination in metastatic uveal melanoma patients. Am J Ophthalmol. 2014;158(5):939-47. https://doi.org/10.1016/j.ajo.2014.07.014

60. Bol KF, van den Bosch T, Schreibelt G, Mensink HW, Keunen JE, Kiliç E, et al. Adjuvant Dendritic Cell Vaccination in High-Risk Uveal Melanoma. Ophthalmology. 2016;123(10):2265-7. https://doi.org/10.1016/j.ophtha.2016. 06.027.

61. Su Z, Dannull J, Yang BK, Dahm P, Coleman D, Yancey D, Sichi S, Niedzwiecki D, Boczkowski D, Gilboa E, Vieweg J. Telomerase mRNAtransfected dendritic cells stimulate antigen-specific CD8+ and CD4+ T cell responses in patients with metastatic prostate Cancer. J Immunol. 2005; 174(6):3798-807. https://doi.org/10.4049/jimmunol.174.6.3798.

62. van Tendeloo VF, van de Velde A, van Driessche A, Cools N, Anguille S, Ladell K, Gostick E, Vermeulen K, Pieters K, Nijs G, Stein B, Smits EL, Schroyens WA, Gadisseur AP, Vrelust I, Jorens PG, Goossens H, de Vries IJ, Price DA, Oji Y, Oka Y, Sugiyama H, Berneman ZN. Induction of complete and molecular remissions in acute myeloid leukemia by Wilms' tumor 1 antigen-targeted dendritic cell vaccination. Proc Natl Acad Sci. 2010;107(31): 13824-9. https://doi.org/10.1073/pnas.1008051107

63. Bol KF, Aarntzen EHJG, Hout FEMI't, Schreibelt G, Creemers JHA, Lesterhuis WJ, et al. Favorable overall survival in stage III melanoma patients after adjuvant dendritic cell vaccination. Oncolmmunology. 2016;5(1):e1057673.

64. Gu Y-Z, Zhao X, Song X-R. Ex vivo pulsed dendritic cell vaccination against cancer. Acta Pharmacol Sin. 2020;41(7):959-69. https://doi.org/10.1038/s41401-020-0415-5 .

65. Wu TC, Guarnieri FG, Staveley-O'Carroll KF, Viscidi RP, Levitsky HI, Hedrick L, Cho KR, August JT, Pardoll DM. Engineering an intracellular pathway for major histocompatibility complex class II presentation of antigens. Proc Natl Acad Sci U S A. 1995;92(25):11671-5. https://doi.org/10.1073/pnas.92.25.11671 .

66. Bonehill A, Heirman C, Tuyaerts S, Michiels A, Breckpot K, Brasseur F, Zhang $Y$, van der Bruggen $P$, Thielemans K. Messenger RNA-electroporated dendritic cells presenting MAGE-A3 simultaneously in HLA class I and class I| molecules. J Immunol. 2004;172(11):6649-57. https://doi.org/10.4049/ jimmunol.172.11.6649

67. Kreiter S, Selmi A, Diken M, Sebastian M, Osterloh P, Schild H, et al. Increased antigen presentation efficiency by coupling antigens to MHC class I trafficking signals. J Immunol. 2007;180(1):309-18.
68. Nair SK, Boczkowski D, Morse M, Cumming Rl, Lyerly HK, Gilboa E. Induction of primary carcinoembryonic antigen (CEA)-specific cytotoxic T lymphocytes in vitro using human dendritic cells transfected with RNA. Nat Biotechnol. 1998;16(4):364-9. https://doi.org/10.1038/nbt0498-364

69. Peters KB, Archer GE, Norberg P, Xie W, Threatt S, Lipp ES, et al. Safety of nivolumab in combination with dendritic cell vaccines in recurrent highgrade glioma. JCO. 2019;37(15\_suppl):e13526.

70. Vlahovic G, Archer GE, Reap E, Desjardins A, Peters KB, Randazzo D, et al. Phase I trial of combination of antitumor immunotherapy targeted against cytomegalovirus (CMV) plus regulatory T-cell inhibition in patients with newly-diagnosed glioblastoma multiforme (GBM). JCO. 2016;34(15\_suppl): e13518.

71. Dannull J, Nair S, Su Z, Boczkowski D, DeBeck C, Yang B, Gilboa E, Vieweg J. Enhancing the immunostimulatory function of dendritic cells by transfection with mRNA encoding OX40 ligand. Blood. 2005;105(8):3206-13. https://doi.org/10.1182/blood-2004-10-3944

72. Grünebach F, Kayser K, Weck MM, Müller MR, Appel S, Brossart P. Cotransfection of dendritic cells with RNA coding for HER-2/neu and 4-1BBL increases the induction of tumor antigen specific cytotoxic $T$ lymphocytes. Cancer Gene Ther. 2005;12(9):749-56. https://doi.org/10.1038/sj.cgt.7700842.

73. Tuyaerts S, van Meirvenne S, Bonehill A, Heirman C, Corthals J, Waldmann $H$, Breckpot K, Thielemans K, Aerts JL. Expression of human GITRL on myeloid dendritic cells enhances their immunostimulatory function but does not abrogate the suppressive effect of CD4+CD25+ regulatory T cells. J Leukoc Biol. 2007;82(1):93-105. https://doi.org/10.1189/jlb.0906568 .

74. Tcherepanova IY, Adams MD, Feng X, Hinohara A, Horvatinovich J, Calderhead D, Healey D, Nicolette CA. Ectopic expression of a truncated CD40L protein from synthetic post-transcriptionally capped RNA in dendritic cells induces high levels of IL-12 secretion. BMC Mol Biol. 2008;9(1):90. https://doi.org/10.1186/1471-2199-9-90

75. Daneshmandi S, Pourfathollah AA, Forouzandeh-Moghaddam M. Enhanced CD40 and ICOSL expression on dendritic cells surface improve anti-tumor immune responses; effectiveness of mRNA/chitosan nanoparticles. Immunopharmacol Immunotoxicol. 2018:40(5):375-86. https://doi.org/10.1 080/08923973.2018.1510959

76. Levin N, Pato A, Cafri G, Eisenberg G, Peretz T, Margalit A, Lotem M, Gross G. Spontaneous activation of antigen-presenting cells by genes encoding truncated homo-Oligomerizing derivatives of CD40.J Immunother. 2017; 40(2):39-50. https://doi.org/10.1097/CJI.0000000000000150 .

77. Bonehill A, Tuyaerts S, Van Nuffel AMT, Heirman C, Bos TJ, Fostier K, et al. Enhancing the T-cell stimulatory capacity of human dendritic cells by coelectroporation with CD40L, CD70 and constitutively active TLR4 encoding mRNA. Mol Ther. 2008;16(6):1170-80. https://doi.org/10.1038/mt.2008.77 .

78. Bonehill A, van Nuffel AMT, Corthals J, Tuyaerts S, Heirman C, Francois V, et al. Single-step antigen loading and activation of dendritic cells by mRNA electroporation for the purpose of therapeutic vaccination in melanoma patients. Clin Cancer Res. 2009;15(10):3366-75. https://doi.org/10.1158/10780432.CCR-08-2982

79. Pen JJ, de Keersmaecker B, Maenhout SK, Van Nuffel AMT, Heirman C, Corthals J, et al. Modulation of regulatory $T$ cell function by monocytederived dendritic cells matured through electroporation with mRNA encoding CD40 ligand, constitutively active TLR4, and CD70. J Immunol. 2013;191(4):1976-83. https://doi.org/10.4049/jimmunol.1201008

80. Naka T, Iwahashi M, Nakamura M, Ojima T, Nakamori M, Ueda K, Katsuda M, Miyazawa M, Ishida K, Yamaue $\mathrm{H}$. Tumor vaccine therapy against recrudescent tumor using dendritic cells simultaneously transfected with tumor RNA and granulocyte macrophage colony-stimulating factor RNA. Cancer Sci. 2008;99(2):407-13. https://doi.org/10.1111/j.1349-7006.2007. 00698.x.

81. Bontkes HJ, Kramer D, Ruizendaal JJ, Kueter EWM, van Tendeloo VFI, Meijer CJLM, et al. Dendritic cells transfected with interleukin-12 and tumorassociated antigen messenger RNA induce high avidity cytotoxic T cells. Gene Ther. 2006;14(4):366-75. https://doi.org/10.1038/sj.gt.3302874

82. Minkis K, Kavanagh DG, Alter G, Bogunovic D, O'Neill D, Adams S, Pavlick A, Walker BD, Brockman MA, Gandhi RT, Bhardwaj N. Type 2 Bias of T cells expanded from the blood of melanoma patients switched to type 1 by IL12p70 mRNA-transfected dendritic cells. Cancer Res. 2008;68(22):9441-50. https://doi.org/10.1158/0008-5472.CAN-08-0900 .

83. van den Bergh J, Willemen Y, Lion E, van Acker $H$, de Reu H, Anguille $S$, Goossens H, Berneman Z, van Tendeloo V, Smits E. Transpresentation of interleukin-15 by IL-15/L-15Ra mRNA-engineered human dendritic cells 
boosts antitumoral natural killer cell activity. Oncotarget. 2015;6(42):4412333. https://doi.org/10.18632/oncotarget.6536.

84. van den Bergh JMJ, Smits ELJM, Versteven M, de Reu H, Berneman ZN, van Tendeloo VFI, et al. Characterization of Interleukin-15-Transpresenting dendritic cells for clinical use. J Immunol Res. 2017;2017:1975902.

85. Carralot J-P, Probst J, Hoerr I, Scheel B, Teufel R, Jung G, Rammensee HG, Pascolo S. Polarization of immunity induced by direct injection of naked sequence-stabilized mRNA vaccines. Cell Mol Life Sci. 2004;61(18):2418-24. https://doi.org/10.1007/s00018-004-4255-0 .

86. Kreiter S, Selmi A, Diken M, Koslowski M, Britten CM, Huber C, Türeci Ö, Sahin U. Intranodal vaccination with naked antigen-encoding RNA elicits potent prophylactic and therapeutic Antitumoral immunity. Cancer Res. 2010;70(22):9031-40. https://doi.org/10.1158/0008-5472.CAN-10-0699 .

87. Bialkowski $L$, van Weijnen $A$, van der Jeught $K$, Renmans $D$, Daszkiewicz $L$, Heirman C, Stangé G, Breckpot K, Aerts JL, Thielemans K. Intralymphatic mRNA vaccine induces CD8 T-cell responses that inhibit the growth of mucosally located tumours. Sci Rep. 2016;6(1):22509. https://doi.org/10.103 8/srep22509.

88. van Lint S, Goyvaerts C, Maenhout S, Goethals L, Disy A, Benteyn D, Pen J, Bonehill A, Heirman C, Breckpot K, Thielemans K. Preclinical evaluation of TriMix and antigen mRNA-based antitumor therapy. Cancer Res. 2012;72(7): 1661-71. https://doi.org/10.1158/0008-5472.CAN-11-2957

89. Sahin U, Derhovanessian E, Miller M, Kloke B-P, Simon P, Löwer M, Bukur V, Tadmor AD, Luxemburger U, Schrörs B, Omokoko T, Vormehr M, Albrecht C, Paruzynski A, Kuhn AN, Buck J, Heesch S, Schreeb KH, Müller F, Ortseifer I, Vogler I, Godehardt E, Attig S, Rae R, Breitkreuz A, Tolliver C, Suchan M, Martic G, Hohberger A, Sorn P, Diekmann J, Ciesla J, Waksmann O, Brück AK, Witt M, Zillgen M, Rothermel A, Kasemann B, Langer D, Bolte S, Diken M, Kreiter S, Nemecek R, Gebhardt C, Grabbe S, Höller C, Utikal J, Huber C, Loquai $C$, Türeci Ö. Personalized RNA mutanome vaccines mobilize polyspecific therapeutic immunity against cancer. Nature. 2017;547(7662):222-6. https://doi.org/10.1038/nature23003 .

90. Rittig SM, Haentschel M, Weimer KJ, Heine A, Muller MR, Brugger W, Horger MS, Maksimovic O, Stenzl A, Hoerr I, Rammensee HG, Holderried TAW, Kanz $L$, Pascolo S, Brossart P. Intradermal vaccinations with RNA coding for TAA generate CD8+ and CD4+ immune responses and induce clinical benefit in vaccinated patients. Mol Ther. 2011;19(5):990-9. https://doi.org/10.1038/mt.2 010.289 .

91. Diken M, Kreiter S, Selmi A, Britten CM, Huber C, Türeci Ö, Sahin U. Selective uptake of naked vaccine RNA by dendritic cells is driven by macropinocytosis and abrogated upon DC maturation. Gene Ther. 2011; 18(7):702-8. https://doi.org/10.1038/gt.2011.17

92. Selmi A, Vascotto F, Kautz-Neu K, Türeci Ö, Sahin U, von Stebut E, Diken M, Kreiter S. Uptake of synthetic naked RNA by skin-resident dendritic cells via macropinocytosis allows antigen expression and induction of T-cell responses in mice. Cancer Immunol Immunother. 2016;65(9):1075-83. https://doi.org/10.1007/s00262-016-1869-7 .

93. Weide B, Carralot J-P, Reese A, Scheel B, Eigentler TK, Hoerr I, Rammensee HG, Garbe C, Pascolo S. Results of the first phase I/II clinical vaccination trial with direct injection of mRNA. J Immunother. 2008;31(2):180-8. https://doi. org/10.1097/CJl.0b013e31815ce501

94. Vormehr M, Türeci Ö, Sahin U. Harnessing tumor mutations for truly individualized Cancer vaccines. Annu Rev Med. 2019;70(1):395-407. https:// doi.org/10.1146/annurev-med-042617-101816.

95. Zeng C, Zhang C, Walker PG, Dong Y. Formulation and Delivery Technologies for mRNA Vaccines. Curr Top Microbiol Immunol. 2020. https://doi.org/10.1007/82_2020_217.

96. Kowalczyk A, Doener F, Zanzinger K, Noth J, Baumhof P, Fotin-Mleczek M, et al. Self-adjuvanted mRNA vaccines induce local innate immune responses that lead to a potent and boostable adaptive immunity. Vaccine. 2016; 34(33):3882-93. https://doi.org/10.1016/j.vaccine.2016.05.046.

97. Papachristofilou A, Hipp MM, Klinkhardt U, Früh M, Sebastian M, Weiss C, Pless M, Cathomas R, Hilbe W, Pall G, Wehler T, Alt J, Bischoff H, Geißler M, Griesinger F, Kallen KJ, Fotin-Mleczek M, Schröder A, Scheel B, Muth A, Seibel T, Stosnach C, Doener F, Hong HS, Koch SD, Gnad-Vogt U, Zippelius A. Phase Ib evaluation of a self-adjuvanted protamine formulated mRNA-based active cancer immunotherapy, Bl1361849 (CV9202), combined with local radiation treatment in patients with stage IV non-small cell lung cancer. J Immunother Cancer. 2019;7(1):38. https://doi.org/10.1186/s40425-019-0520-5 .

98. Sebastian M, Papachristofilou A, Weiss C, Früh M, Cathomas R, Hilbe W, Wehler T, Rippin G, Koch SD, Scheel B, Fotin-Mleczek M, Heidenreich R,
Kallen KJ, Gnad-Vogt U, Zippelius A. Phase lb study evaluating a selfadjuvanted mRNA cancer vaccine (RNActive ${ }^{\circledR}$ ) combined with local radiation as consolidation and maintenance treatment for patients with stage IV nonsmall cell lung cancer. BMC Cancer. 2014;14(1):748. https://doi.org/10.11 86/1471-2407-14-748

99. Weide B, Pascolo S, Scheel B, Derhovanessian E, Pflugfelder A, Eigentler TK, Pawelec G, Hoerr I, Rammensee HG, Garbe C. Direct injection of protamineprotected mRNA: results of a phase $1 / 2$ vaccination trial in metastatic melanoma patients. J Immunother. 2009;32(5):498-507. https://doi.org/10.1 097/CJl.0b013e3181a00068.

100. Sebastian M, Schröder A, Scheel B, Hong HS, Muth A, von Boehmer L, Zippelius A, Mayer F, Reck M, Atanackovic D, Thomas M, Schneller F, Stöhlmacher J, Bernhard H, Gröschel A, Lander T, Probst J, Strack T, Wiegand V, Gnad-Vogt U, Kallen KJ, Hoerr I, von der Muelbe F, Fotin-Mleczek M, Knuth A, Koch SD. A phase I/lla study of the mRNA-based cancer immunotherapy CV9201 in patients with stage IIIB/IV non-small cell lung cancer. Cancer Immunol Immunother. 2019;68(5):799-812. https://doi.org/1 0.1007/s00262-019-02315-x.

101. Scheibenbogen C, Schadendorf D, Bechrakis NE, Nagorsen D, Hofmann U, Servetopoulou F, Letsch A, Philipp A, Foerster MH, Schmittel A, Thiel E, Keilholz U. Effects of granulocyte-macrophage colony-stimulating factor and foreign helper protein as immunologic adjuvants on the T-cell response to vaccination with tyrosinase peptides. Int J Cancer. 2003;104(2):188-94. https://doi.org/10.1002/ijc.10961

102. Malone RW, Felgner PL, Verma IM. Cationic liposome-mediated RNA transfection. Proc Natl Acad Sci. 1989;86(16):6077-81. https://doi.org/10.1 073/pnas.86.16.6077

103. Phua KKL. Towards targeted delivery systems: ligand conjugation strategies for mRNA nanoparticle tumor vaccines. J Immunol Res. 2015;2015:680620.

104. Perche F, Benvegnu T, Berchel M, Lebegue L, Pichon C, Jaffrès P-A, Midoux $P$. Enhancement of dendritic cells transfection in vivo and of vaccination against B16F10 melanoma with mannosylated histidylated lipopolyplexes loaded with tumor antigen messenger RNA. Nanomedicine. 2011;7(4):44553. https://doi.org/10.1016/j.nano.2010.12.010

105. Van der Jeught K, De Koker S, Bialkowski L, Heirman C, Tjok JP, Perche F, et al. Dendritic Cell Targeting mRNA Lipopolyplexes Combine Strong Antitumor T-Cell Immunity with Improved Inflammatory Safety. ACS Nano. 2018;12(10):9815-29. https://doi.org/10.1021/acsnano.8b00966.

106. Guan S, Rosenecker J. Nanotechnologies in delivery of mRNA therapeutics using nonviral vector-based delivery systems. Gene Ther. 2017;24(3):133-43. https://doi.org/10.1038/gt.2017.5

107. Kreiter S, Vormehr M, van de Roemer N, Diken M, Löwer M, Diekmann J, Boegel S, Schrörs B, Vascotto F, Castle JC, Tadmor AD, Schoenberger SP, Huber C, Türeci Ö, Sahin U. Mutant MHC class II epitopes drive therapeutic immune responses to cancer. Nature. 2015;520(7549):692-6. https://doi. org/10.1038/nature14426.

108. Grunwitz C, Salomon N, Vascotto F, Selmi A, Bukur T, Diken M, Kreiter S, Türeci Ö, Sahin U. HPV16 RNA-LPX vaccine mediates complete regression of aggressively growing HPV-positive mouse tumors and establishes protective T cell memory. Oncolmmunology. 2019;8(9):e1629259. https://doi.org/10.1 080/2162402X.2019.1629259

109. Salomon N, Vascotto F, Selmi A, Vormehr M, Quinkhardt J, Bukur T, Schrörs B, Löewer M, Diken M, Türeci Ö, Sahin U, Kreiter S. A liposomal RNA vaccine inducing neoantigen-specific CD4+ T cells augments the antitumor activity of local radiotherapy in mice. Oncolmmunology. 2020;9(1):1771925. https:// doi.org/10.1080/2162402X.2020.1771925.

110. Reinhard K, Rengstl B, Oehm P, Michel K, Billmeier A, Hayduk N, Klein O, Kuna K, Ouchan Y, Wöll S, Christ E, Weber D, Suchan M, Bukur T, Birtel M, Jahndel V, Mroz K, Hobohm K, Kranz L, Diken M, Kühlcke K, Türeci Ö, Sahin $U$. An RNA vaccine drives expansion and efficacy of claudin-CAR-T cells against solid tumors. Science. 2020;367(6476):446-53. https://doi.org/10.112 6/science.aay5967

111. Sahin U, Muik A, Derhovanessian E, Vogler I, Kranz LM, Vormehr M, Baum A, Pascal K, Quandt J, Maurus D, Brachtendorf S, Lörks V, Sikorski J, Hilker R, Becker D, Eller AK, Grützner J, Boesler C, Rosenbaum C, Kühnle MC, Luxemburger U, Kemmer-Brück A, Langer D, Bexon M, Bolte S, Karikó K, Palanche T, Fischer B, Schultz A, Shi PY, Fontes-Garfias C, Perez JL, Swanson KA, Loschko J, Scully IL, Cutler M, Kalina W, Kyratsous CA, Cooper D, Dormitzer PR, Jansen KU, Türeci Ö. COVID-19 vaccine BNT162b1 elicits human antibody and TH1 T cell responses. Nature. 2020;586(7830):594-9. https://doi.org/10.1038/s41586-020-2814-7 . 
112. Sahin U, Muik A, Vogler I, Derhovanessian E, Kranz LM, Vormehr M, et al. BNT162b2 induces SARS-CoV-2-neutralising antibodies and T cells in humans. medRxiv. 2020;12.09.20245175. https://doi.org/10.1101/2020.12.09.2 0245175.

113. Mulligan MJ, Lyke KE, Kitchin N, Absalon J, Gurtman A, Lockhart S, Neuzil K, Raabe V, Bailey R, Swanson KA, Li P, Koury K, Kalina W, Cooper D, FontesGarfias C, Shi PY, Türeci Ö, Tompkins KR, Walsh EE, Frenck R, Falsey AR, Dormitzer PR, Gruber WC, Sahin U, Jansen KU. Phase I/II study of COVID-19 RNA vaccine BNT162b1 in adults. Nature. 2020;586(7830):589-93. https://doi. org/10.1038/s41586-020-2639-4 .

114. Baden LR, El Sahly HM, Essink B, Kotloff K, Frey S, Novak R, et al. Efficacy and safety of the mRNA-1273 SARS-CoV-2 vaccine. N Engl J Med. 2021;384(5): 403-16. https://doi.org/10.1056/NEJMoa2035389.

115. Vogel AB, Kanevsky I, Che Y, Swanson KA, Muik A, Vormehr M, Kranz LM, Walzer KC, Hein S, Güler A, Loschko J, Maddur MS, Ota-Setlik A, Tompkins K, Cole J, Lui BG, Ziegenhals T, Plaschke A, Eisel D, Dany SC, Fesser S, Erbar S, Bates F, Schneider D, Jesionek B, Sänger B, Wallisch AK, Feuchter $Y$, Junginger $H$, Krumm SA, Heinen AP, Adams-Quack P, Schlereth J, Schille S, Kröner C, de la Caridad Güimil Garcia R, Hiller T, Fischer L, Sellers RS, Choudhary S, Gonzalez O, Vascotto F, Gutman MR, Fontenot JA, Hall-Ursone S, Brasky K, Griffor MC, Han S, Su AAH, Lees JA, Nedoma NL, Mashalidis EH, Sahasrabudhe PV, Tan CY, Pavliakova D, Singh G, Fontes-Garfias C, Pride M, Scully IL, Ciolino T, Obregon J, Gazi M, Carrion R Jr, Alfson KJ, Kalina WV, Kaushal D, Shi PY, Klamp T, Rosenbaum C, Kuhn AN, Türeci Ö, Dormitzer PR, Jansen KU, Sahin U. BNT162b vaccines protect rhesus macaques from SARSCoV-2. Nature. 2021. https://doi.org/10.1038/s41586-021-03275-y .

116. Dagan N, Barda N, Kepten E, Miron O, Perchik S, Katz MA, Hernán MA, Lipsitch M, Reis B, Balicer RD. BNT162b2 mRNA Covid-19 vaccine in a Nationwide mass vaccination setting. N Engl J Med. 2021. https://doi.org/1 0.1056/NEJMoa2101765

117. Petter E, Mor O, Zuckerman N, Oz-Levi D, Younger A, Aran D et al. Initial real world evidence for lower viral load of individuals who have been vaccinated by BNT162b2: cold Spring Harbor laboratory; 2021.

118. Bahl K, Senn JJ, Yuzhakov O, Bulychev A, Brito LA, Hassett KJ, Laska ME, Smith M, Almarsson Ö, Thompson J, Ribeiro A(M), Watson M, Zaks T, Ciaramella G. Preclinical and clinical demonstration of immunogenicity by mRNA vaccines against H10N8 and H7N9 influenza viruses. Mol Ther. 2017; 25(6):1316-27. https://doi.org/10.1016/j.ymthe.2017.03.035 .

119. Meyer M, Huang E, Yuzhakov O, Ramanathan P, Ciaramella G, Bukreyev A. Modified mRNA-based vaccines elicit robust immune responses and protect Guinea pigs from Ebola virus disease. J Infect Dis. 2018;217(3):451-5. https:// doi.org/10.1093/infdis/jix592.

120. Richner JM, Himansu S, Dowd KA, Butler SL, Salazar V, Fox JM, et al. Modified mRNA Vaccines Protect against Zika Virus Infection. Cell. 2017; 168(6):1114-1125.e10.

121. Pardi N, Hogan MJ, Naradikian MS, Parkhouse K, Cain DW, Jones L, Moody MA, Verkerke HP, Myles A, Willis E, LaBranche CC, Montefiori DC, Lobby JL, Saunders KO, Liao HX, Korber BT, Sutherland LL, Scearce RM, Hraber PT, Tombácz I, Muramatsu H, Ni H, Balikov DA, Li C, Mui BL, Tam YK, Krammer F, Karikó K, Polacino P, Eisenlohr LC, Madden TD, Hope MJ, Lewis MG, Lee KK, Hu SL, Hensley SE, Cancro MP, Haynes BF, Weissman D. Nucleoside-modified mRNA vaccines induce potent $\mathrm{T}$ follicular helper and germinal center $\mathrm{B}$ cell responses. J Exp Med. 2018;215(6):1571-88. https://doi.org/10.1084/jem.20171450 .

122. Corbett KS, Flynn B, Foulds KE, Francica JR, Boyoglu-Barnum S, Werner AP, Flach B, O'Connell S, Bock KW, Minai M, Nagata BM, Andersen H, Martinez DR, Noe AT, Douek N, Donaldson MM, Nji NN, Alvarado GS, Edwards DK, Flebbe DR, Lamb E, Doria-Rose NA, Lin BC, Louder MK, O'Dell S, Schmidt SD, Phung E, Chang LA, Yap C, Todd JPM, Pessaint L, van Ry A, Browne S, Greenhouse J, Putman-Taylor T, Strasbaugh A, Campbell TA, Cook A, Dodson A, Steingrebe K, Shi W, Zhang Y, Abiona OM, Wang L, Pegu A, Yang ES, Leung K, Zhou T, Teng IT, Widge A, Gordon I, Novik L, Gillespie RA, Loomis RJ, Moliva JI, Stewart-Jones G, Himansu S, Kong WP, Nason MC, Morabito KM, Ruckwardt TJ, Ledgerwood JE, Gaudinski MR, Kwong PD, Mascola JR, Carfi A, Lewis MG, Baric RS, McDermott A, Moore IN, Sullivan NJ, Roederer M, Seder RA, Graham BS. Evaluation of the mRNA-1273 vaccine against SARS-CoV-2 in nonhuman Primates. N Engl J Med. 2020;383(16): 1544-55. https://doi.org/10.1056/NEJMoa2024671

123. Cafri G, Gartner JJ, Zaks T, Hopson K, Levin N, Paria BC, Parkhurst MR, Yossef R, Lowery FJ, Jafferji MS, Prickett TD, Goff SL, McGowan CT, Seitter S, Shindorf ML, Parikh A, Chatani PD, Robbins PF, Rosenberg SA. mRNA vaccine-induced neoantigen-specific $T$ cell immunity in patients with gastrointestinal cancer. J Clin Invest. 2020;130(11):5976-88. https://doi.org/1 $0.1172 / \mathrm{JCl} 134915$

124. Miao L, Li L, Huang Y, Delcassian D, Chahal J, Han J, Shi Y, Sadtler K, Gao W, Lin J, Doloff JC, Langer R, Anderson DG. Delivery of mRNA vaccines with heterocyclic lipids increases anti-tumor efficacy by STING-mediated immune cell activation. Nat Biotechnol. 2019;37(10):1174-85. https://doi.org/10.1038/ s41587-019-0247-3.

125. Maude SL, Laetsch TW, Buechner J, Rives S, Boyer M, Bittencourt H, Bader P, Verneris MR, Stefanski HE, Myers GD, Qayed M, de Moerloose B, Hiramatsu $\mathrm{H}$, Schlis K, Davis KL, Martin PL, Nemecek ER, Yanik GA, Peters C, Baruchel A, Boissel N, Mechinaud F, Balduzzi A, Krueger J, June CH, Levine BL, Wood P, Taran T, Leung M, Mueller KT, Zhang Y, Sen K, Lebwohl D, Pulsipher MA, Grupp SA. Tisagenlecleucel in children and young adults with B-cell lymphoblastic Leukemia. N Engl J Med. 2018;378(5):439-48. https://doi.org/1 0.1056/NEJMoa1709866

126. Neelapu SS, Locke FL, Bartlett NL, Lekakis LJ, Miklos DB, Jacobson CA, Braunschweig I, Oluwole OO, Siddiqi T, Lin Y, Timmerman JM, Stiff PJ, Friedberg JW, Flinn IW, Goy A, Hill BT, Smith MR, Deol A, Farooq U, MCSweeney P, Munoz J, Avivi I, Castro JE, Westin JR, Chavez JC, Ghobadi A, Komanduri KV, Levy R, Jacobsen ED, Witzig TE, Reagan P, Bot A, Rossi J, Navale L, Jiang Y, Aycock J, Elias M, Chang D, Wiezorek J, Go WY. Axicabtagene Ciloleucel CAR T-cell therapy in refractory large B-cell lymphoma. N Engl J Med. 2017;377(26):2531-44. https://doi.org/10.1056/ NEJMoa1707447.

127. Lee JM, Yoon SH, Kim H-S, Kim SY, Sohn H-J, Oh S-T, Oh IH, Kim TG. Direct and indirect antitumor effects by human peripheral blood lymphocytes expressing both chimeric immune receptor and interleukin-2 in ovarian cancer xenograft model. Cancer Gene Ther. 2010;17(10):742-50. https://doi. org/10.1038/cgt.2010.30

128. Carlsten M, Levy E, Karambelkar A, Li L, Reger R, Berg M, et al. Efficient mRNA-based genetic engineering of human NK cells with high-affinity CD16 and CCR7 augments rituximab-induced ADCC against lymphoma and targets NK cell migration toward the lymph node-associated chemokine CCL19. Front Immunol. 2016;7:105.

129. Ng YY, Tay JCK, Wang S. CXCR1 expression to improve anti-Cancer efficacy of intravenously injected CAR-NK cells in mice with peritoneal Xenografts. Mol Ther Oncolytics. 2020;16:75-85. https://doi.org/10.1016/j.omto.2019.12. 006 .

130. Mitchell DA, Karikari I, Cui X, Xie W, Schmittling R, Sampson JH. Selective modification of antigen-specific T cells by RNA electroporation. Hum Gene Ther. 2008;19(5):511-21. https://doi.org/10.1089/hum.2007.115 .

131. Dörrie J, Schaft N, Müller I, Wellner V, Schunder T, Hänig J, Oostingh GJ, Schön MP, Robert C, Kämpgen E, Schuler G. Introduction of functional chimeric E/L-selectin by RNA electroporation to target dendritic cells from blood to lymph nodes. Cancer Immunol Immunother. 2008;57(4):467-77. https://doi.org/10.1007/s00262-007-0385-1 .

132. Ren J, Liu X, Fang $\mathrm{C}$, Jiang $\mathrm{S}$, June $\mathrm{CH}$, Zhao Y. Multiplex genome editing to generate universal CAR T cells resistant to PD1 inhibition. Clin Cancer Res. 2017;23(9):2255-66. https://doi.org/10.1158/1078-0432.CCR-16-1300

133. Zhao Y, Zheng Z, Cohen CJ, Gattinoni L, Palmer DC, Restifo NP, et al. Highefficiency transfection of primary human and mouse T lymphocytes using RNA electroporation. Mol Ther. 2006;13(1):151-9. https://doi.org/10.1016/j. ymthe.2005.07.688.

134. Yoon SH, Lee JM, Woo SJ, Park MJ, Park JS, Kim HS, et al. Transfer of Her-2/ neu specificity into cytokine-induced killer (CIK) cells with RNA encoding chimeric immune receptor (CIR). J Clin Immunol. 2009;29(6):806-14. https:// doi.org/10.1007/s10875-009-9308-6.

135. Boissel $L$, Betancur M, Wels WS, Tuncer $H$, Klingemann $H$. Transfection with mRNA for CD19 specific chimeric antigen receptor restores NK cell mediated killing of CLL cells. Leuk Res. 2009;33(9):1255-9. https://doi.org/10.1016/j.leukres.2008.11.024 .

136. Schaft N, Dörrie J, Müller I, Beck V, Baumann S, Schunder T, et al. A new way to generate cytolytic tumor-specific T cells: Electroporation of RNA coding for a T cell receptor into T lymphocytes. Cancer Immunol Immunother. 2006;55(9):1132-41. https://doi.org/10.1007/s00262-005-0098-2.

137. Birkholz K, Hombach A, Krug C, Reuter S, Kershaw M, Kämpgen E, Schuler G, Abken $H$, Schaft N, Dörrie J. Transfer of mRNA encoding recombinant immunoreceptors reprograms CD4+ and CD8+ T cells for use in the adoptive immunotherapy of cancer. Gene Ther. 2009;16(5):596-604. https:/doi.org/10.1038/gt.2008.189 .

138. Almåsbak H, Rian E, Hoel HJ, Pulè M, Wälchli S, Kvalheim G, Gaudernack G, Rasmussen AM. Transiently redirected T cells for adoptive transfer. Cytotherapy. 2011;13(5):629-40. https://doi.org/10.3109/14653249.2010.542461 . 
139. Barrett DM, Zhao Y, Liu X, Jiang S, Carpenito C, Kalos M, Carroll RG, June CH, Grupp SA. Treatment of advanced leukemia in mice with mRNA engineered T cells. Hum Gene Ther. 2011;22(12):1575-86. https://doi.org/10.1089/hum.2 011.070 .

140. Kenderian SS, Ruella M, Shestova O, Klichinsky M, Aikawa V, Morrissette JJD, Scholler J, Song D, Porter DL, Carroll M, June CH, Gill S. CD33-specific chimeric antigen receptor $T$ cells exhibit potent preclinical activity against human acute myeloid leukemia. Leukemia. 2015;29(8):1637-47. https://doi. org/10.1038/leu.2015.52

141. Ang WX, Li Z, Chi Z, Du SH, Chen C, Tay JC, et al. Intraperitoneal immunotherapy with $T$ cells stably and transiently expressing anti-EpCAM CAR in xenograft models of peritoneal carcinomatosis. Oncotarget. 2017; 8(8):13545-59. https://doi.org/10.18632/oncotarget.14592.

142. Rabinovich PM, Komarovskaya ME, Wrzesinski SH, Alderman JL, BudakAlpdogan T, Karpikov A, Guo H, Flavell RA, Cheung NK, Weissman SM, Bahceci E. Chimeric receptor mRNA transfection as a tool to generate antineoplastic lymphocytes. Hum Gene Ther. 2009;20(1):51-61. https://doi. org/10.1089/hum.2008.068

143. Singh N, Liu X, Hulitt J, Jiang S, June CH, Grupp SA, Barrett DM, Zhao Y. Nature of tumor control by permanently and transiently modified GD2 chimeric antigen receptor T cells in xenograft models of neuroblastoma. Cancer Immunol Res. 2014;2(11):1059-70. https://doi.org/10.1158/2326-6066. CIR-14-0051

144. Lehner M, Götz G, Proff J, Schaft N, Dörrie J, Full F, Ensser A, Muller YA, Cerwenka A, Abken H, Parolini O, Ambros PF, Kovar H, Holter W. Redirecting $T$ cells to Ewing's sarcoma family of tumors by a chimeric NKG2D receptor expressed by lentiviral transduction or mRNA transfection. PLoS One. 2012 7(2):e31210. https://doi.org/10.1371/journal.pone.0031210 .

145. Krug C, Birkholz K, Paulus A, Schwenkert M, Schmidt P, Hoffmann N, et al. Stability and activity of MCSP-specific chimeric antigen receptors (CARs) depend on the scFv antigen-binding domain and the protein backbone. Cancer Immunol Immunother. 2015;64(12):1623-35. https://doi.org/10.1007/ s00262-015-1767-4.

146. Almåsbak H, Walseng E, Kristian A, Myhre SEM, Munthe $L$, et al. Inclusion of an IgG1-Fc spacer abrogates efficacy of CD19 CAR T cells in a xenograft mouse model. Gene Ther. 2015;22(5):391-403. https://doi.org/10.1038/gt.201 5.4

147. Inoo K, Inagaki R, Fujiwara K, Sasawatari S, Kamigaki T, Nakagawa S, Okada N. Immunological quality and performance of tumor vessel-targeting CAR-T cells prepared by mRNA-EP for clinical research. Mol Ther Oncolytics. 2016;3: 16024. https://doi.org/10.1038/mto.2016.24

148. Li Z, Chi Z, Ang WX, Chen C, Tay JC, Ng YY, et al. Experimental treatment of colorectal cancer in mice with human T cells electroporated with NKG2D RNA CAR. Immunotherapy. 2020;12(10):733-48. https://doi.org/10.2217/imt-2 019-0137.

149. Schutsky K, Song DG, Lynn R, Smith JB, Poussin M, Figini M, Zhao Y, Powell DJ Jr. Rigorous optimization and validation of potent RNA CAR T cell therapy for the treatment of common epithelial cancers expressing folate receptor. Oncotarget. 2015;6(30):28911-28. https://doi.org/10.18632/oncota rget.5029

150. Zhao Y, Moon E, Carpenito C, Paulos CM, Liu X, Brennan AL, Chew A, Carroll RG, Scholler J, Levine BL, Albelda SM, June CH. Multiple injections of Electroporated autologous $T$ cells expressing a chimeric antigen receptor mediate regression of human disseminated tumor. Cancer Res. 2010;70(22): 9053-61. https://doi.org/10.1158/0008-5472.CAN-10-2880

151. Fujiwara K, Sasawatari S, Nakai S, Imaeda K, Nagai S, Matsuno Y, et al. Predicting the Efficacy and Safety of TACTICS (Tumor Angiogenesis-Specific CAR-T Cells Impacting Cancers) Therapy for Soft Tissue Sarcoma Patients. Cancers (Basel). 2020;12(10):2735. https://doi.org/10.3390/cancers12102735.

152. Foster JB, Choudhari N, Perazzelli J, Storm J, Hofmann TJ, Jain P, Storm PB, Pardi N, Weissman D, Waanders AJ, Grupp SA, Karikó K, Resnick AC, Barrett DM. Purification of mRNA encoding chimeric antigen receptor is critical for generation of a robust T-cell response. Hum Gene Ther. 2019;30(2):168-78. https://doi.org/10.1089/hum.2018.145

153. Krug C, Wiesinger M, Abken H, Schuler-Thurner B, Schuler G, Dörrie J, et al. A GMP-compliant protocol to expand and transfect cancer patient T cells with mRNA encoding a tumor-specific chimeric antigen receptor. Cancer Immunol Immunother. 2014;63(10):999-1008. https://doi.org/10.1007/s002 62-014-1572-5.

154. Wiesinger M, März J, Kummer M, Schuler G, Dörrie J, Schuler-Thurner B, et al. Clinical-Scale Production of CAR-T Cells for the Treatment of
Melanoma Patients by mRNA Transfection of a CSPG4-Specific CAR under Full GMP Compliance. Cancers (Basel). 2019;11(8):1198. https://doi.org/10.33 90/cancers 11081198

155. Rabinovich PM, Komarovskaya ME, Ye Z-J, Imai C, Campana D, Bahceci E, Weissman SM. Synthetic messenger RNA as a tool for gene therapy. Hum Gene Ther. 2006;17(10):1027-35. https://doi.org/10.1089/hum.2006.17.1027 .

156. Lin L, Cho S-F, Xing L, Wen K, Li Y, Yu T, et al. Preclinical evaluation of CD8+ anti-BCMA mRNA CAR T cells for treatment of multiple myeloma. Leukemia. 2021;35(3):752-763. https://doi.org/10.1038/s41375-020-0951-5.

157. Xiao L, Cen D, Gan H, Sun Y, Huang N, Xiong H, et al. Adoptive Transfer of NKG2D CAR mRNA-Engineered Natural Killer Cells in Colorectal Cancer Patients. Mol Ther. 2019;27(6):1114-25. https://doi.org/10.1016/j.ymthe.2019. 03.011.

158. Maus MV, Haas AR, Beatty GL, Albelda SM, Levine BL, Liu X, Zhao Y, Kalos M, June $\mathrm{CH}$. T cells expressing chimeric antigen receptors can cause anaphylaxis in humans. Cancer Immunol Res. 2013;1(1):26-31. https://doi. org/10.1158/2326-6066.CIR-13-0006

159. Beatty GL, Haas AR, Maus MV, Torigian DA, Soulen MC, Plesa G, Chew A, Zhao Y, Levine BL, Albelda SM, Kalos M, June CH. Mesothelin-specific chimeric antigen receptor mRNA-engineered T cells induce anti-tumor activity in solid malignancies. Cancer Immunol Res. 2014;2(2):112-20. https://doi.org/10.1158/2326-6066.CIR-13-0170 .

160. Beatty GL, O'Hara MH, Lacey SF, Torigian DA, Nazimuddin F, Chen F, et al. Activity of Mesothelin-specific chimeric antigen receptor $T$ cells against pancreatic carcinoma metastases in a phase 1 trial. Gastroenterology. 2018; 155(1):29-32. https://doi.org/10.1053/j.gastro.2018.03.029

161. Tchou J, Zhao Y, Levine BL, Zhang PJ, Davis MM, Melenhorst JJ, Kulikovskaya I, Brennan AL, Liu X, Lacey SF, Posey AD Jr, Williams AD, So A, Conejo-Garcia JR, Plesa G, Young RM, McGettigan S, Campbell J, Pierce RH, Matro JM, DeMichele AM, Clark AS, Cooper LJ, Schuchter LM, Vonderheide $\mathrm{RH}$, June $\mathrm{CH}$. Safety and efficacy of Intratumoral injections of chimeric antigen receptor (CAR) T cells in metastatic breast Cancer. Cancer Immunol Res. 2017;5(12):1152-61. https://doi.org/10.1158/23266066.CIR-17-0189

162. Barrett DM, Liu X, Jiang S, June CH, Grupp SA, Zhao Y. Regimen-specific effects of RNA-modified chimeric antigen receptor T cells in mice with advanced leukemia. Hum Gene Ther. 2013;24(8):717-27. https://doi.org/10.1 089/hum.2013.075.

163. Svoboda J, Rheingold SR, Gill SI, Grupp SA, Lacey SF, Kulikovskaya I, Suhoski MM, Melenhorst JJ, Loudon B, Mato AR, Nasta SD, Landsburg DJ, Youngman MR, Levine BL, Porter DL, June CH, Schuster SJ. Nonviral RNA chimeric antigen receptor-modified T cells in patients with Hodgkin lymphoma. Blood. 2018;132(10):1022-6. https://doi.org/10.1182/blood-2018-03-837609

164. Cummins KD, Frey N, Nelson AM, Schmidt A, Luger S, Isaacs RE, et al. Treating Relapsed / Refractory (RR) AML with Biodegradable Anti-CD123 CAR Modified T Cells. Blood. 2017;130(Supplement 1):1359.

165. Chang K, Pastan I, Willingham MC. Isolation and characterization of a monoclonal antibody, K1, reactive with ovarian cancers and normal mesothelium. Int J Cancer. 1992:50(3):373-81. https://doi.org/10.1002/ijc.2910500308 .

166. Gill S, Tasian SK, Ruella M, Shestova O, Li Y, Porter DL, et al. Preclinical targeting of human acute myeloid leukemia and myeloablation using chimeric antigen receptor-modified T cells. Blood. 2014;123(15):2343-54. https://doi.org/10.1182/blood-2013-09-529537.

167. Tasian SK, Kenderian SS, Shen F, Ruella M, Shestova O, Kozlowski M, Li Y, Schrank-Hacker A, Morrissette JJD, Carroll M, June CH, Grupp SA, Gill S. Optimized depletion of chimeric antigen receptor T cells in murine xenograft models of human acute myeloid leukemia. Blood. 2017;129(17): 2395-407. https://doi.org/10.1182/blood-2016-08-736041

168. Harrer DC, Simon B, Fujii S-I, Shimizu K, Uslu U, Schuler G, Gerer KF, Hoyer S, Dörrie J, Schaft N. RNA-transfection of $\gamma / \delta T$ cells with a chimeric antigen receptor or an $\alpha / \beta$ T-cell receptor: a safer alternative to genetically engineered $\alpha / \beta$ T cells for the immunotherapy of melanoma. BMC Cancer. 2017;17(1):551. https://doi.org/10.1186/s12885-017-3539-3 .

169. Ang WX, Ng YY, Xiao L, Chen C, Li Z, Chi Z, Tay JCK, Tan WK, Zeng J, Toh HC, Wang S. Electroporation of NKG2D RNA CAR improves Vy9V $\delta 2 T$ cell responses against human solid tumor Xenografts. Mol Ther Oncolytics. 2020;17:421-30. https://doi.org/10.1016/j.omto.2020.04.013 .

170. Simon B, Wiesinger M, März J, Wistuba-Hamprecht K, Weide B, SchulerThurner B, et al. The Generation of CAR-Transfected Natural Killer T Cells for the Immunotherapy of Melanoma. Int J Mol Sci. 2018;19(8):2365. https://doi. org/10.3390/ijms19082365. 
171. Boissel L, Betancur M, Lu W, Wels WS, Marino T, van Etten RA, Klingemann $\mathrm{H}$. Comparison of mRNA and lentiviral based transfection of natural killer cells with chimeric antigen receptors recognizing lymphoid antigens. Leuk Lymphoma. 2012;53(5):958-65. https://doi.org/1 0.3109/10428194.2011.634048

172. Shimasaki N, Fujisaki H, Cho D, Masselli M, Lockey T, Eldridge P, et al. A clinically adaptable method to enhance the cytotoxicity of natural killer cells against B-cell malignancies. Cytotherapy. 2012;14(7):830-40. https://doi.org/1 0.3109/14653249.2012.671519.

173. Pierpont TM, Limper CB, Richards KL. Past, present, and future of rituximabthe World's first oncology monoclonal antibody therapy. Front Oncol. 2018; 8:163. https://doi.org/10.3389/fonc.2018.00163

174. Hudis CA. Trastuzumab--mechanism of action and use in clinical practice. N Engl J Med. 2007;357(1):39-51. https://doi.org/10.1056/NEJMra043186

175. Thran M, Mukherjee J, Pönisch M, Fiedler K, Thess A, Mui BL, Hope MJ, Tam YK, Horscroft N, Heidenreich R, Fotin-Mleczek M, Shoemaker CB, Schlake T. mRNA mediates passive vaccination against infectious agents, toxins, and tumors. EMBO Mol Med. 2017;9(10):1434-47. https://doi.org/10.15252/ emmm.201707678.

176. Rybakova Y, Kowalski PS, Huang Y, Gonzalez JT, Heartlein MW, DeRosa F, et al. mRNA delivery for therapeutic anti-HER2 antibody expression in vivo. Mol Ther. 2019;27(8):1415-23. https://doi.org/10.1016/j.ymthe.2019.05.012.

177. Spiess C, Zhai Q, Carter PJ. Alternative molecular formats and therapeutic applications for bispecific antibodies. Mol Immunol. 2015;67(2 Pt A):95-106. https://doi.org/10.1016/j.molimm.2015.01.003.

178. Stadler CR, Bähr-Mahmud H, Celik L, Hebich B, Roth AS, Roth RP, et al. Elimination of large tumors in mice by mRNA-encoded bispecific antibodies. Nat Med. 2017;23(7):815-7. https://doi.org/10.1038/nm.4356.

179. Ballesteros-Briones MC, Martisova E, Casales E, Silva-Pilipich N, Buñuales M, Galindo J, Mancheño U, Gorraiz M, Lasarte JJ, Kochan G, Escors D, SanchezPaulete AR, Melero I, Prieto J, Hernandez-Alcoceba R, Hervas-Stubbs S, Smerdou C. Short-term local expression of a PD-L1 blocking antibody from a self-replicating RNA vector induces potent antitumor responses. Mol Ther. 2019;27(11):1892-905. https://doi.org/10.1016/j.ymthe.2019.09.016

180. Boczkowski D, Lee J, Pruitt S, Nair S. Dendritic cells engineered to secrete anti-GITR antibodies are effective adjuvants to dendritic cell-based immunotherapy. Cancer Gene Ther. 2009;16(12):900-11. https://doi.org/10.1 038/cgt.2009.39

181. Pruitt SK, Boczkowski D, de Rosa N, Haley NR, Morse MA, Tyler DS, Dannull J, Nair S. Enhancement of anti-tumor immunity through local modulation of CTLA-4 and GITR by dendritic cells. Eur J Immunol. 2011;41(12):3553-63. https://doi.org/10.1002/eji.201141383

182. Patel MR, Bauer TM, Jimeno A, Wang D, LoRusso P, Do KT, et al. A phase I study of mRNA-2752, a lipid nanoparticle encapsulating mRNAs encoding human OX40L, IL-23, and IL-36y, for intratumoral (iTu) injection alone and in combination with durvalumab. JCO. 2020;38(15_suppl):3092.

183. Liu X, Barrett DM, Jiang S, Fang C, Kalos M, Grupp SA, June CH, Zhao Y. Improved anti-leukemia activities of adoptively transferred $T$ cells expressing bispecific T-cell engager in mice. Blood Cancer J. 2016;6(6):e430. https://doi. org/10.1038/bcj.2016.38 .

184. Zhou T, Damsky W, Weizman OE, McGeary MK, Hartmann KP, Rosen CE, et al. IL-18BP is a secreted immune checkpoint and barrier to IL-18 immunotherapy. Nature. 2020;583(7817):609-14. https://doi.org/10.1038/s41 586-020-2422-6

185. Wang X, Zhao X, Feng C, Weinstein A, Xia R, Wen W, et al. IL-36y Transforms the Tumor Microenvironment and Promotes Type 1 Lymphocyte-Mediated Antitumor Immune Responses. Cancer Cell. 2015;28(3):296-306. https://doi. org/10.1016/j.ccell.2015.07.014.

186. Nastala CL, Edington HD, McKinney TG, Tahara H, Nalesnik MA, Brunda MJ, et al. Recombinant IL-12 administration induces tumor regression in association with IFN-gamma production. J Immunol. 1994;153(4):1697-706.

187. Jiang T, Zhou C, Ren S. Role of IL-2 in cancer immunotherapy. Oncolmmunology. 2016;5(6):e1163462. https://doi.org/10.1080/2162402X.2 016.1163462

188. Kranz LM. Complementary effects of RNA encoded, extended half-life IL2 and IL7 synergize in modulating T cell responses and anti-tumoral efficacy. Abstract P620, SITC 2019.

189. Vormehr M. Substantial improvement of cancer immunotherapy by an RNA encoded extend-ed half-life Interleukin-2 variant. Abstract P626, SITC 2019.

190. Ring AM, Lin J-X, Feng D, Mitra S, Rickert M, Bowman GR, Pande VS, Li P, Moraga I, Spolski R, Özkan E, Leonard WJ, Garcia KC. Mechanistic and structural insight into the functional dichotomy between IL-2 and IL-15. Nat Immunol. 2012;13(12):1187-95. https://doi.org/10.1038/ni.2449

191. Waldmann TA. The shared and contrasting roles of IL2 and IL15 in the life and death of normal and neoplastic lymphocytes: implications for cancer therapy. Cancer Immunol Res. 2015;3(3):219-27. https://doi.org/10.1158/232 6-6066.CIR-15-0009

192. Conlon KC, Lugli E, Welles HC, Rosenberg SA, Fojo AT, Morris JC, Fleisher TA, Dubois SP, Perera LP, Stewart DM, Goldman CK, Bryant BR, Decker JM, Chen J, Worthy T'YA, Figg WD Sr, Peer CJ, Sneller MC, Lane HC, Yovandich JL, Creekmore SP, Roederer M, Waldmann TA. Redistribution, hyperproliferation, activation of natural killer cells and CD8 T cells, and cytokine production during first-in-human clinical trial of recombinant human interleukin-15 in patients with cancer. J Clin Oncol. 2015;33(1):74-82. https://doi.org/10.1200/ JCO.2014.57.3329

193. Rowley J, Monie A, Hung C-F, Wu T-C. Expression of IL-15RA or an IL-15/IL15RA fusion on CD8+ T cells modifies adoptively transferred T-cell function in cis. Eur J Immunol. 2009;39(2):491-506. https://doi.org/10.1002/eji.20083 8594

194. Leonard JP, Sherman ML, Fisher GL, Buchanan LJ, Larsen G, Atkins MB, Sosman JA, Dutcher JP, Vogelzang NJ, Ryan JL. Effects of single-dose interleukin-12 exposure on interleukin-12-associated toxicity and interferongamma production. Blood. 1997;90(7):2541-8.

195. Motzer RJ, Rakhit A, Schwartz LH, Olencki T, Malone TM, Sandstrom K, et al. Phase I trial of subcutaneous recombinant human interleukin-12 in patients with advanced renal cell carcinoma. Clin Cancer Res. 1998;4(5):1183-91.

196. Etxeberria I, Bolaños E, Quetglas JI, Gros A, Villanueva A, Palomero J, et al. Intratumor adoptive transfer of IL-12 mRNA transiently engineered antitumor CD8 + T cells. Cancer Cell. 2019;36(6):613-29. https://doi.org/10.1 016/j.ccell.2019.10.006

197. Hewitt SL, Bailey D, Zielinski J, Apte A, Musenge F, Karp R, Burke S, Garcon F, Mishra A, Gurumurthy S, Watkins A, Arnold K, Moynihan J, ClancyThompson E, Mulgrew K, Adjei G, Deschler K, Potz D, Moody G, Leinster DA, Novick S, Sulikowski M, Bagnall C, Martin P, Lapointe JM, Si H, Morehouse C, Sedic M, Wilkinson RW, Herbst R, Frederick JP, Luheshi N. Intratumoral IL12 mRNA therapy promotes TH1 transformation of the tumor microenvironment. Clin Cancer Res. 2020;26(23):6284-98. https://doi.org/1 0.1158/1078-0432.CCR-20-0472

198. Lai I, Swaminathan S, Baylot V, Mosley A, Dhanasekaran R, Gabay M, et al. Lipid nanoparticles that deliver IL-12 messenger RNA suppress tumorigenesis in MYC oncogene-driven hepatocellular carcinoma. J Immunother Cancer. 2018; 6(1):125. https://doi.org/10.1186/s40425-018-0431-x.

199. Hewitt SL, Bai A, Bailey D, Ichikawa K, Zielinski J, Karp R, et al. Durable anticancer immunity from intratumoral administration of IL-23, IL-36Y, and OX40L mRNAs. Sci Transl Med. 2019;11(477):eaat9143. https://doi.org/10.112 6/scitranslmed.aat9143.

200. Malkova NV, Tolstykh T, Levit M, Theilhaber J, Hebert A, Atchison K, et al. Abstract 4451: Combination of local mRNA immunotherapy with systemic immune checkpoint blockade demonstrates anti-tumor activity across a diverse range of preclinical syngeneic tumor models. In: American Association for Cancer Research; 2020.

201. van der Jeught $K$, Joe PT, Bialkowski L, Heirman C, Daszkiewicz L, Liechtenstein T, Escors D, Thielemans K, Breckpot K. Intratumoral administration of mRNA encoding a fusokine consisting of IFN- $\beta$ and the ectodomain of the TGF- $\beta$ receptor $\|$ potentiates antitumor immunity. Oncotarget. 2014;5(20):10100-13. https://doi.org/10.18632/oncotarget.2463 .

202. Pato A, Eisenberg G, Machlenkin A, Margalit A, Cafri G, Frankenburg S, Merims $\mathrm{S}$, Peretz T, Lotem M, Gross G. Messenger RNA encoding constitutively active toll-like receptor 4 enhances effector functions of human T cells. Clin Exp Immunol. 2015;182(2):220-9. https://doi.org/10.1111/cei.12688 .

203. Levin N, Weinstein-Marom H, Pato A, Itzhaki O, Besser MJ, Eisenberg G, Peretz T, Lotem M, Gross G. Potent activation of human T cells by mRNA encoding constitutively active CD40. J Immunol. 2018;201(10):2959-68. https://doi.org/10.4049/jimmunol.1701725.

204. Weinstein-Marom H, Pato A, Levin N, Susid K, Itzhaki O, Besser MJ, et al. Membrane-attached cytokines expressed by mRNA electroporation act as potent T-Cell adjuvants. J Immunother. 2016;39(2):60-70. https://doi.org/10.1 097/CJ.0000000000000109.

205. Weinstein-Marom H, Levin N, Pato A, Shmuel N, Sharabi-Nov A, Peretz T, et al. Combined expression of genetic adjuvants via mRNA electroporation exerts multiple immunostimulatory effects on antitumor T cells. J Immunother. 2019; 42(2):43-50. https://doi.org/10.1097/Cll.0000000000000252. 
206. van Lint S, Renmans D, Broos K, Goethals L, Maenhout S, Benteyn D, Goyvaerts C, du Four S, van der Jeught K, Bialkowski L, Flamand V, Heirman C, Thielemans K, Breckpot K. Intratumoral delivery of TriMix mRNA results in T-cell activation by cross-presenting dendritic cells. Cancer Immunol Res. 2016;4(2):146-56. https://doi.org/10.1158/2326-6066.CIR-15-0163 .

207. Jimeno A. A phase $1 / 2$, open-label, multicenter, dose escalation and efficacy study of mRNA-2416, a lipid nanoparticle encapsulated mRNA encoding human OX40L, for intratumoral injection alone or in combination with durvalumab for patients with advanced malignancies. Abstract CT032, AACR Annual Meeting 2020.

208. Haabeth OAW, Blake TR, McKinlay CJ, Tveita AA, Sallets A, Waymouth RM, et al. Local delivery of Ox40l, Cd80, and Cd86 mRNA kindles global anticancer immunity. Cancer Res. 2019;79(7):1624-34. https://doi.org/10.11 58/0008-5472.CAN-18-2867.

\section{Publisher's Note}

Springer Nature remains neutral with regard to jurisdictional claims in published maps and institutional affiliations.

Ready to submit your research? Choose BMC and benefit from:

- fast, convenient online submission

- thorough peer review by experienced researchers in your field

- rapid publication on acceptance

- support for research data, including large and complex data types

- gold Open Access which fosters wider collaboration and increased citations

- maximum visibility for your research: over $100 \mathrm{M}$ website views per year

At BMC, research is always in progress.

Learn more biomedcentral.com/submissions 